\title{
Article \\ Clinical Implications of Serum Hepatitis B Virus Pregenomic RNA Kinetics in Chronic Hepatitis B Patients Receiving Antiviral Treatment and Those Achieving HBsAg Loss
}

\author{
I-Chin $\mathrm{Wu}^{+}{ }^{+}$, , Wen-Chun Liu ${ }^{\dagger}$, Yen-Cheng Chiu, Hung-Chih Chiu, Pin-Nan Cheng and Ting-Tsung Chang * \\ Department of Internal Medicine, National Cheng Kung University Hospital, College of Medicine, \\ National Cheng Kung University, Tainan 70403, Taiwan; wichin@mail.ncku.edu.tw (I.-C.W.); \\ graceliu8911@gmail.com (W.-C.L.); tannoy63352@gmail.com (Y.-C.C.); toad.chiu@gmail.com (H.-C.C.); \\ pncheng@mail.ncku.edu.tw (P.-N.C.) \\ * Correspondence: ttchang@mail.ncku.edu.tw \\ + These authors contributed equally to this work.
}

\section{check for} updates

Citation: Wu, I-C.; Liu, W.-C.; Chiu, Y.-C.; Chiu, H.-C.; Cheng, P.-N.;

Chang, T.-T. Clinical Implications of Serum Hepatitis B Virus Pregenomic RNA Kinetics in Chronic Hepatitis B Patients Receiving Antiviral Treatment and Those Achieving HBsAg Loss. Microorganisms 2021, 9 , 1146. https://doi.org/10.3390/ microorganisms 9061146

Academic Editor: Teresa Santantonio

Received: 27 April 2021

Accepted: 25 May 2021

Published: 26 May 2021

Publisher's Note: MDPI stays neutral with regard to jurisdictional claims in published maps and institutional affiliations.

Copyright: (c) 2021 by the authors. Licensee MDPI, Basel, Switzerland. This article is an open access article distributed under the terms and conditions of the Creative Commons Attribution (CC BY) license (https:// creativecommons.org/licenses/by/ $4.0 /)$.
Abstract: Serum hepatitis B virus (HBV) pregenomic RNA (pgRNA) is correlated with covalently closed circular DNA. We aimed to investigate the utility of serum HBV pgRNA in chronic hepatitis $B$ patients receiving nucleos $(t) i d e$ analogue treatment and those achieving HBsAg loss. One hundred and eighty-five patients were enrolled for studying long-term HBV pgRNA kinetics during treatment. Twenty patients achieving HBsAg loss after treatment were enrolled for examining HBV pgRNA kinetics around HBsAg loss. HBV pgRNA significantly decreased in the high baseline HBV pgRNA ( $\geq 6 \log$ copies $/ \mathrm{mL}$ ) group but significantly increased in the low baseline HBV pgRNA $(<4 \log$ copies $/ \mathrm{mL})$ group after 3-month entecavir treatment. Among the 20 patients achieving HBsAg loss, 13 (65\%) patients had serum HBV pgRNA higher than the limit of detection (LOD, 1466 copies $/ \mathrm{mL}$ ) when they achieved HBsAg loss. Finally, all 20 patients had HBV pgRNA going below the LOD within 3 years after achieving HBsAg loss. In conclusion, baseline serum HBV pgRNA alone is insufficient for predicting the trajectory of HBV pgRNA. Most patients still had HBV pgRNA higher than the LOD when they achieved HBsAg loss. Further studies on HBV pgRNA kinetics around HBsAg loss would provide an enhanced basis for further applications of HBV pgRNA.

Keywords: entecavir; hepatitis B surface antigen; hepatitis B virus; nucleos(t)ide analogue; pregenomic RNA; viral kinetics

\section{Introduction}

Chronic hepatitis B virus (HBV) infection is an important health problem worldwide. The WHO estimated that 257 million people were living with chronic HBV infection in 2015 [1]. The 5-year cumulative incidence of cirrhosis is $8-20 \%$ in untreated patients, and the 5-year cumulative risk of hepatic decompensation is $20 \%$ among those with cirrhosis [2]. The annual risk of hepatocellular carcinoma (HCC) is $2-5 \%$ in cirrhotic patients [3]. Current treatment guidelines recommend pegylated interferon, entecavir (a nucleoside analog), and tenofovir (a nucleotide analogue) as preferred treatments for chronic HBV infection $[2,4,5]$. Pegylated interferon treatment achieves hepatitis $\mathrm{B}$ e antigen ( $\mathrm{HBeAg})$ seroconversion in approximately one-third of patients with HBeAg-positive chronic hepatitis B (CHB), but this treatment is associated with a number of side effects that limit its use [6]. Entecavir and tenofovir are broadly used because of their efficacy, safety, and convenience. However, long-term treatment is necessary to maintain efficacy due to the persistence of covalently closed circular DNA (cccDNA) [7].

Serum HBsAg, which is derived from cccDNA and integrated HBV DNA sequences, could be found in complete virions, subviral particles, empty virions, and HBV RNAcontaining virion-like particles [8]. Quantification of serum HBsAg is helpful in defining the 
phase of HBV infection, identifying the patients most likely to respond to interferon therapy, and determining the likelihood of HBV reactivation after withdrawal of nucleos(t)ide analogue treatment [9]. Hepatitis B core-related antigen ( $\mathrm{HBcrAg}$ ) is a serological marker that simultaneously measures three proteins coded by the precore/core region, including $\mathrm{HBeAg}$, hepatitis B core antigen, and a $22 \mathrm{kDa}$ precore protein (p22cr) [10]. HBcrAg was shown to correlate with intrahepatic cccDNA [11,12] and associated with disease progression [13], HCC development [14,15], treatment responses [16,17], and virological relapse after cessation of treatment $[18,19]$.

HBV pregenomic RNA (pgRNA), which is transcribed from cccDNA, is the template for both reverse transcription of relaxed circular DNA and translation of viral polymerase and core proteins [20]. Circulating HBV pgRNA could be found in the blood of CHB patients. Previous studies have shown that serum HBV pgRNA is encapsidated and is present in virion-like particles [21,22]. HBV pgRNA might have diagnostic advantages because it carries viral genetic information and because its quantification is not affected by immune complexes of antibodies and viral antigens [23]. Several studies have shown that serum HBV pgRNA is correlated with intrahepatic cccDNA [23-25] and is associated with viral rebound after withdrawal of treatment [22,26-28]. However, the serum HBV pgRNA kinetics in $\mathrm{CHB}$ patients receiving long-term nucleos(t)ide analogue therapy and those achieving HBsAg loss are not fully understood. This study investigated (1) long-term HBV pgRNA kinetics during entecavir treatment, (2) the factors associated with virological relapse after cessation of entecavir therapy, (3) serum HBV pgRNA kinetics in the patients achieving HBsAg loss, and (4) the factors associated with HBsAg loss.

\section{Materials and Methods}

\subsection{Patient Enrollment}

Patients were retrospectively enrolled from our clinics, previous clinical trials, and databases in National Cheng Kung University Hospital. All the CHB patients in Part I and Part II received at least 2 years of consecutive entecavir treatment, which was the only antiviral therapy during the study period. The indication for antiviral therapy mostly followed the Asian Pacific Association for the Study of the Liver HBV treatment guideline [5]. The exclusion criteria were as follows: (1) treatment history with nucleos(t)ide analogues or interferon, (2) coinfection with hepatitis $C$ virus or human immunodeficiency virus, (3) end-stage renal disease, (4) systemic chemotherapy or immunotherapy due to malignancy, and (5) post-organ transplantation [29]. Finally, $185 \mathrm{CHB}$ patients were enrolled for studying the long-term kinetics of serum HBV pgRNA during entecavir therapy (Part I) and $47 \mathrm{CHB}$ patients for analyzing the factors associated with virological relapse after cessation of entecavir therapy (Part II), 55 CHB patients who had achieved HBsAg loss, 20 healthy subjects with negative HBsAg but positive antibody to hepatitis B core antigen (anti-HBc), and 17 healthy controls with negative HBsAg and negative anti-HBc for determining the expression of serum HBV pgRNA after HBsAg loss (Part III). 20 CHB patients received nucleos(t)ide analogue treatment with HBsAg loss for investigating HBV pgRNA kinetics in the patients achieving HBsAg loss (Part IV), $20 \mathrm{CHB}$ patients received nucleos $(\mathrm{t})$ ide analogue treatment with $\mathrm{HBs} A g$ loss, and $141 \mathrm{CHB}$ patients received nucleos(t)ide analogue treatment without HBsAg loss for assessing the factors associated with HBsAg loss (Part V) (Figure 1). This study was approved by the Institutional Review Board of National Cheng Kung University Hospital. Informed consents were provided by study participants.

\subsection{Patient Monitoring}

The patients in Part I and II were followed up at 3- to 6-month (12- to 24-week) intervals through liver biochemistry and serum HBV DNA tests, as well as abdominal sonography. In HBeAg-positive patients, HBeAg was assessed every 3 to 6 months until negative results were obtained. Liver cirrhosis was diagnosed by liver biopsy, abdominal sonography, computed tomography (CT), magnetic resonance imaging (MRI), or portal 
hypertension (esophageal or cardiac varices revealed by esophagogastroduodenoscopy). Hepatocellular carcinoma was diagnosed by histological examination or dynamic imaging studies (CT or MRI). The upper limit of normal (ULN) of alanine aminotransferase (ALT) was $50 \mathrm{U} / \mathrm{mL}$ in male patients and $35 \mathrm{U} / \mathrm{mL}$ in female patients at National Cheng Kung University Hospital.

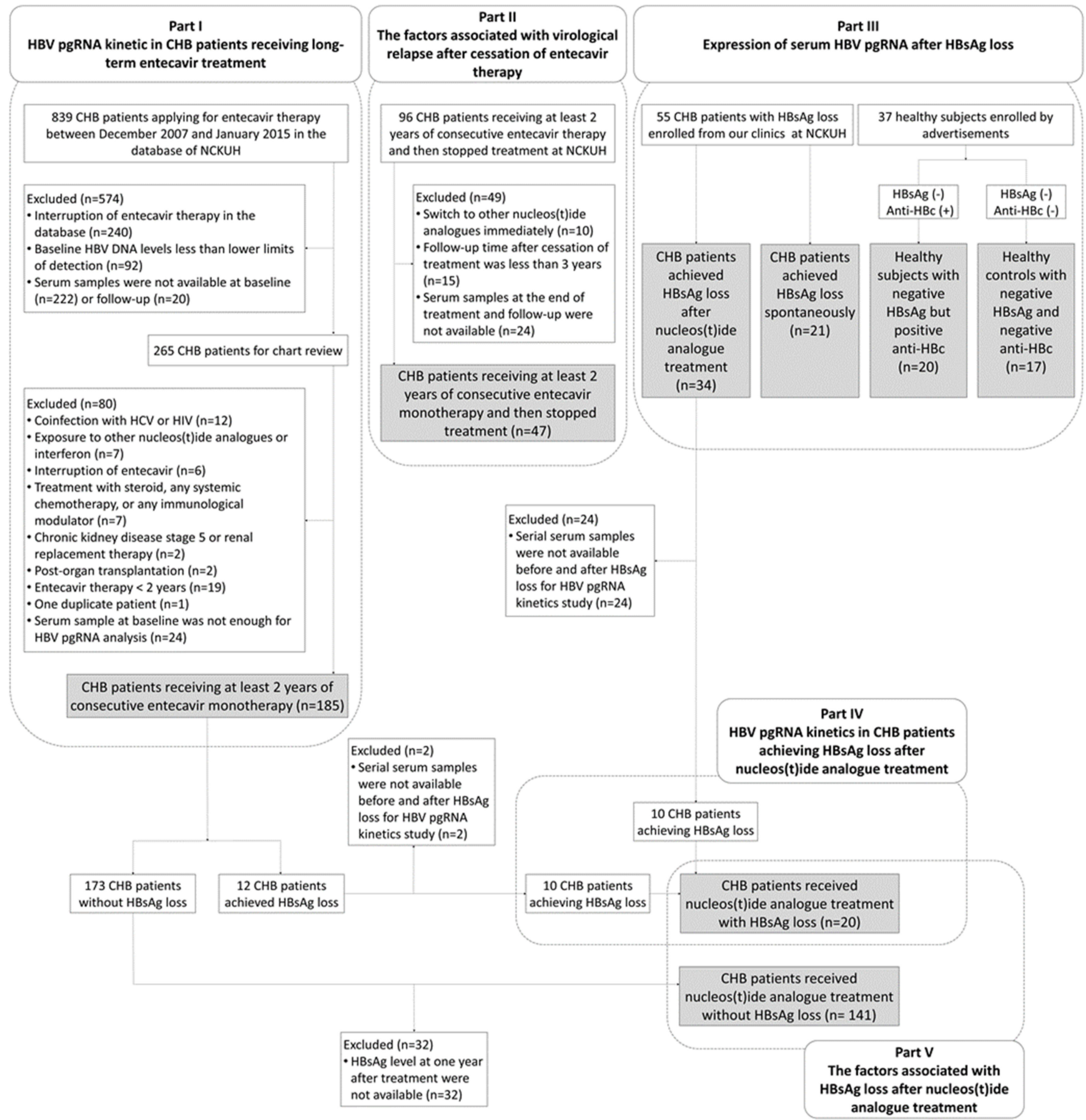

Figure 1. Patient flow diagram. Abbreviations: Anti-HBc, antibody to hepatitis B core antigen; $\mathrm{CHB}$, chronic hepatitis B; HBsAg, hepatitis B surface antigen; $\mathrm{HBV}$, hepatitis B virus; $\mathrm{HCV}$, hepatitis $\mathrm{C}$ virus; $\mathrm{HIV}$, human immunodeficiency viruses; NCKU, National Cheng Kung University.

For studying the kinetics of serum HBV pgRNA, HBV DNA, and HBsAg during entecavir therapy, serum HBV pgRNA and HBV DNA quantification was performed at baseline and the 3rd month (12th week), 6th month (24th week), 12th month (48th week), 
and 60th month (240th week) of treatment, and serum HBsAg quantification was performed at baseline and the 1st year (48th week) and 5th year (240th week) of treatment. Virological response was defined as undetectable serum HBV DNA $(<60 \mathrm{IU} / \mathrm{mL})$ after entecavir therapy.

For analyzing the factors associated with virological relapse, these patients were monitored for up to 3 years after cessation of entecavir therapy. Serum HBV pgRNA, HBV DNA, and HBsAg levels were determined at the end of treatment. Virological relapse was defined as serum HBV DNA level >2000 IU/mL after cessation of entecavir therapy.

\subsection{Quantification of Serum HBsAg}

Serum HBsAg levels were measured using the Architect HBsAg assay (Abbott, Chicago, IL, USA), with a limit of detection (LOD) of $0.05 \mathrm{IU} / \mathrm{mL}$. For statistical analysis, serum samples with HBsAg levels below LOD were recorded as $0.04 \mathrm{IU} / \mathrm{mL}(-1.40 \log \mathrm{IU} / \mathrm{mL})$.

\subsection{Quantification of Serum HBV DNA}

Serum HBV DNA levels were determined using the Roche Cobas Amplicor (LOD: $60 \mathrm{IU} / \mathrm{mL}$ ); Roche Cobas TaqMan 48 analyzer (LOD: 29 IU/mL); Roche Cobas AmpliPrep/Cobas TaqMan HBV Test, version 1.0 (LOD: 12 IU/mL); and Roche Cobas AmpliPrep/Cobas TaqMan HBV Test, version 2.0 (LOD: $20 \mathrm{IU} / \mathrm{mL}$ ). For statistical analysis, serum samples with HBV DNA values below LOD and serum samples in which HBV DNA was not detected were recorded as $\mathrm{LOD}-1 \mathrm{IU} / \mathrm{mL}$ and $1 \mathrm{IU} / \mathrm{mL}$, respectively.

\subsection{Extraction and Reverse Transcription of $H B V p g R N A$}

HBV RNA was extracted from $150 \mu \mathrm{L}$ of serum using the Total RNA Extraction Miniprep System Kit according to the manufacturer's instructions (Viogene, Taipei, Taiwan) and was treated with DNase I (Thermo Fisher Scientific, Waltham, MA, USA). Isolated HBV RNA was reverse transcribed using RevertAid reverse transcriptase (Thermo Fisher Scientific, Waltham, MA, USA) with an HBV pgRNA-specific reverse transcription (RT) primer (Supplementary Table S1). Before commencing RT, $20 \mu \mathrm{L}$ of RNA, $1 \mu \mathrm{L}$ of $100 \mu \mathrm{M}$ primer, and $1 \mu \mathrm{L}$ of $10 \mathrm{mM}$ dNTPs (Thermo Fisher Scientific, Waltham, MA, USA) were mixed, incubated at $70{ }^{\circ} \mathrm{C}$ for $5 \mathrm{~min}$, and then placed immediately on ice for $1 \mathrm{~min}$. RT was then initiated with the addition of the RT reaction mixture to ensure a final volume of $35 \mu \mathrm{L}$ at a final concentration of $1 \times$ RT buffer, $1 \mu \mathrm{L}$ of RNAse inhibitor (Life Technologies), and $1 \mu \mathrm{L}$ of RevertAid reverse transcriptase (Life Technologies). Cycling conditions were $42{ }^{\circ} \mathrm{C}$ for $60 \mathrm{~min}$, followed by $75{ }^{\circ} \mathrm{C}$ for $5 \mathrm{~min}$. cDNA samples were maintained at $4{ }^{\circ} \mathrm{C}$ before proceeding to quantitative real-time polymerase chain reaction (qPCR).

\subsection{Quantification of Serum HBV pgRNA}

Serum HBV pgRNA levels were detected by qPCR on the LightCycler 480 II Real-Time PCR Detection System (Roche, Mannheim, Germany) by using a SYBR Green method. The primers used to detect $3.5 \mathrm{~kb}$ HBV pgRNA are provided in Supplementary Table S1. PCR was used to construct the standards by using each primer from the HBV full genome (accession number: KJ790199) [30], and the PCR products were subsequently ligated into the T\&A ${ }^{\mathrm{TM}}$ Cloning Vector (Yeastern Biotech, New Taipei, Taiwan). The qPCR reaction mixture $(20 \mu \mathrm{L})$ contained $10 \mu \mathrm{L}$ of $2 \times$ GoTaq $^{\circledR}$ Green Master Mix (Promega Corp., Madison, WI, USA), $0.5 \mu \mathrm{L}$ of the forward primer $(10 \mu \mathrm{M}), 0.5 \mu \mathrm{L}$ of the reverse primer $(10 \mu \mathrm{M})$, $1 \mu \mathrm{L}$ of the cDNA template, and $8 \mu \mathrm{L}$ of double distilled water $\left(\mathrm{ddH}_{2} \mathrm{O}\right)$. The reaction mixture was denatured at $95{ }^{\circ} \mathrm{C}$ for $5 \mathrm{~min}$, followed by 40 cycles at $95{ }^{\circ} \mathrm{C}$ for $20 \mathrm{~s}$ and $60{ }^{\circ} \mathrm{C}$ for $40 \mathrm{~s}$. The LOD of serum HBV pgRNA was 1466 copies $/ \mathrm{mL}$, as calculated by probit analysis (Supplementary Table S2). For statistical analysis, 1465 copies $/ \mathrm{mL}$ (3.17 log copies $/ \mathrm{mL}$ ) was recorded as the value for serum samples with HBV pgRNA below LOD or not detected. 


\subsection{HBV Genotyping}

The HBV genotype was determined through melting curve analysis using LightCycler hybridization probes, as described previously [31].

\subsection{Statistical Analysis}

Continuous variables were compared between two groups using Student's $t$-test or the Mann-Whitney test, as appropriate. Continuous variables were compared between three groups using one-way ANOVA or the Kruskal-Wallis test, as appropriate. The distributions of categorical variables were compared using Pearson's chi-squared test or Fisher's exact test when the expected value was less than 5 in $2 \times 2$ tables. The cumulative incidence of virological response, virological relapse, and HBsAg loss was derived using the Kaplan-Meier analysis and was tested using the log-rank test. Multivariate analysis was performed using Cox proportional hazards regression to identify the factors associated with virological responses, virological relapse, and HBsAg loss. Linear mixed models with a random intercept were used for analyzing the longitudinal changes in serum HBV pgRNA, HBsAg, and HBV DNA levels. In this model, groups and time points were considered categorical variables and represented by dummy variables. Statistical analysis was performed using Stata 16.1 (StataCorp, College Station, TX, USA). The results were considered statistically significant at $p<0.05$.

\section{Results}

\subsection{Clinical Characteristics of Patients in the Analysis of HBV pgRNA Kinetics during} Entecavir Therapy

In Part I, $185 \mathrm{CHB}$ patients were enrolled for the analysis of long-term HBV pgRNA kinetics during entecavir therapy. The mean age was $51.0 \pm 12.0$ years, $70.3 \%$ were men, and $29.2 \%$ were HBeAg-positive. At baseline, the mean ALT, HBsAg, HBV DNA, and HBV pgRNA levels were $3.84 \pm 5.84 \times \mathrm{ULN}, 3.15 \pm 0.78 \log \mathrm{IU} / \mathrm{mL}, 5.83 \pm 1.72 \log \mathrm{IU} / \mathrm{mL}$, and $5.07 \pm 1.98 \log$ copies $/ \mathrm{mL}$, respectively. For patients with available data on HBV genotypes, 88 had genotype $B$ and 76 had genotype $C$. The median treatment duration was 4.85 (range, 1.84-11.29) years. As expected, HBeAg-positive patients were younger and had higher baseline HBsAg, higher baseline HBV DNA, higher proportion of genotype C, lower proportion of liver cirrhosis, and later virological responses than HBeAg-negative patients (Table 1).

\subsection{HBV pgRNA Kinetics during Entecavir Treatment}

For analyzing serum HBV pgRNA kinetics during entecavir treatment, patients were categorized into three groups according to baseline HBV pgRNA levels: high, medium, and low baseline HBV pgRNA groups (baseline HBV pgRNA levels of $\geq 6, \geq 4$ and $<6$, and $<4 \log$ copies $/ \mathrm{mL}$, respectively). In the high baseline HBV pgRNA group, serum HBV pgRNA levels decreased rapidly in the first 3 months and remained constant thereafter. In the medium baseline HBV pgRNA group, HBV pgRNA levels decreased gradually in the first 12 months and remained constant thereafter. In the low baseline HBV pgRNA group, HBV pgRNA levels increased in the first 3 months and remained constant thereafter. Compared with the medium and low HBV pgRNA groups, the high baseline HBV pgRNA group had higher HBV pgRNA levels at baseline, 12 months, and 60 months. The high baseline HBV pgRNA group also had higher HBV pgRNA levels at 3 months and 6 months than the low HBV pgRNA group. The medium baseline HBV pgRNA group had higher HBV pgRNA levels at baseline and 3 months compared with the low HBV pgRNA group. No significant differences were detected in HBV pgRNA levels at 6 months, 12 months, and 60 months between the medium and low HBV pgRNA groups (Figure 2). 
Table 1. Clinical characteristics of 185 patients with chronic hepatitis B for studying the kinetics of serum HBV pgRNA during entecavir therapy, categorized by HBeAg status.

\begin{tabular}{|c|c|c|c|c|}
\hline Characteristics & $\begin{array}{l}\text { Total Patients } \\
\quad(n=185)\end{array}$ & $\begin{array}{c}\text { HBeAg-Positive Patients } \\
(n=54)\end{array}$ & $\begin{array}{l}\text { HBeAg-Negative Patients } \\
\qquad(n=131)\end{array}$ & $p^{\mathrm{a}}$ \\
\hline Age (year) & $51.0 \pm 12.0$ & $43.8 \pm 12.5$ & $54.0 \pm 10.5$ & $<0.0001$ \\
\hline Male (\%) & $130 / 185(70.3 \%)$ & $36 / 54(66.7 \%)$ & $94 / 131(71.8 \%)$ & 0.49 \\
\hline HBV genotype (B:C) ${ }^{b}$ & $88: 76$ & $17: 36$ & $71: 40$ & $<0.001$ \\
\hline Baseline ALT (× ULN) & $3.84 \pm 5.84$ & $4.12 \pm 6.63$ & $3.73 \pm 5.51$ & 0.68 \\
\hline Baseline HBsAg $(\log \mathrm{IU} / \mathrm{mL})$ & $3.15 \pm 0.78$ & $3.78 \pm 0.72$ & $2.89 \pm 0.65$ & $<0.0001$ \\
\hline Baseline HBV DNA $(\log \mathrm{IU} / \mathrm{mL})$ & $5.83 \pm 1.72$ & $7.29 \pm 1.32$ & $5.23 \pm 1.49$ & $<0.0001$ \\
\hline $\begin{array}{l}\text { Baseline HBV pgRNA } \\
(\log \text { copies /mL) }\end{array}$ & $5.07 \pm 1.98$ & $5.48 \pm 2.03$ & $4.89 \pm 1.94$ & 0.066 \\
\hline Liver cirrhosis (\%) & $62 / 185(33.5 \%)$ & $12 / 54(22.2 \%)$ & $50 / 131(38.2 \%)$ & 0.037 \\
\hline $\operatorname{HCC}(\%)^{c}$ & $29 / 185(15.7 \%)$ & $5 / 54(9.3 \%)$ & $24 / 131(18.3 \%)$ & 0.12 \\
\hline Duration of entecavir therapy (years) & $4.85(1.84-11.29)$ & $4.43(1.95-8.85)$ & $4.92(1.84-11.29)$ & 0.93 \\
\hline Virological response rate $(\%)^{d}$ & $166 / 171(97.1 \%)$ & $42 / 46(91.3 \%)$ & $124 / 125(99.2 \%)$ & 0.019 \\
\hline Time to virological response (years) & $0.51(0.04-4.88)$ & $1.01(0.22-4.02)$ & $0.46(0.04-4.88)$ & 0.0001 \\
\hline HBeAg seroconversion rate $(\%)$ & & $19 / 54(35.2 \%)$ & & \\
\hline Time to HBeAg seroconversion (years) & & $1.24(0.21-7.49)$ & & \\
\hline $\begin{array}{l}\text { Virological response and } \mathrm{HBeAg} \\
\text { seroconversion rate }(\%)\end{array}$ & & $15 / 45(33.3 \%)$ & & \\
\hline $\begin{array}{l}\text { Time to virological response and } \\
\text { HBeAg seroconversion (years) }\end{array}$ & & $1.07(0.49-4.06)$ & & \\
\hline
\end{tabular}

Continuous variables are expressed as mean \pm standard deviation, except for duration of entecavir therapy, time to virological response, time to $\mathrm{HBeAg}$ seroconversion, and time to virological response and $\mathrm{HBeAg}$ seroconversion, which are expressed as median (range). Significant $p$ values are presented in bold. ${ }^{a} p$ value for $\mathrm{HBeAg}$-positive patients compared with HBeAg-negative patients. ${ }^{\mathrm{b}} \mathrm{HBV}$ genotype was not determined in $1 \mathrm{HBeAg}$-positive patient and $20 \mathrm{HBeAg}$-negative patients because of low baseline $\mathrm{HBV}$ viral loads. ${ }^{\mathrm{c}} \mathrm{HCC}$ was diagnosed before or within half a year of entecavir therapy. ${ }^{\mathrm{d}}$ The virological response (serum HBV DNA $<60 \mathrm{IU} / \mathrm{mL}$ ) was not assessed in eight HBeAg-positive patients and six $\mathrm{HBeAg}$-negative patients because limited serum samples within the first year prevented the virological response from being determined precisely.

Figure 3 shows the serum HBV DNA kinetics during entecavir treatment, categorized by baseline serum HBV pgRNA levels. HBV DNA levels decreased rapidly in the first 3 months and decreased gradually thereafter. The high baseline HBV pgRNA group had higher HBV DNA levels at baseline than did the medium HBV pgRNA group. No significant differences were observed in HBV DNA levels at 3 months, 6 months, 12 months, or 60 months between the high, medium, and low HBV pgRNA groups.

Figure 4 presents the serum HBsAg kinetics during entecavir treatment, categorized by baseline serum HBV pgRNA levels. In the high baseline HBV pgRNA group, HBsAg levels decreased rapidly in the first 12 months and remained constant thereafter. In the medium and low baseline HBV pgRNA groups, HBsAg levels decreased gradually after entecavir therapy initiation. The high baseline HBV pgRNA group had higher HBsAg at baseline compared with the medium and low HBV pgRNA groups. No significant differences were observed in HBsAg levels at 12 months and 60 months between the high, medium, and low HBV pgRNA groups.

Moreover, no significant differences were found in age, sex, HBeAg status, HBV genotype, baseline ALT, and liver cirrhosis status between the high, medium, and low HBV pgRNA groups (Supplementary Table S3). 
Comparisons between time points for a specific group

\begin{tabular}{|c|c|c|c|c|c|c|}
\hline \multirow[b]{2}{*}{ Group } & \multicolumn{6}{|c|}{ Time point } \\
\hline & $\begin{array}{l}\text { Baseline vs. } \\
3 \text { months }\end{array}$ & $\begin{array}{c}\text { Baseline vs. } \\
6 \text { months }\end{array}$ & $\begin{array}{l}\text { Baseline vs. } \\
12 \text { months }\end{array}$ & $\begin{array}{l}\text { Baseline vs. } \\
60 \text { months }\end{array}$ & $\begin{array}{l}3 \text { months vs. } \\
12 \text { months }\end{array}$ & $\begin{array}{l}3 \text { months vs. } \\
60 \text { months }\end{array}$ \\
\hline $\begin{array}{l}\text { Baseline HBV pgRNA } \geq 6 \\
\text { log copies/mL }\end{array}$ & $<0.001$ & $<0.001$ & $<0.001$ & $<0.001$ & & \\
\hline $\begin{array}{l}\text { Baseline HBV pgRNA } \geq 4 \text { and }<6 \\
\text { log copies/mL }\end{array}$ & 0.058 & 0.017 & $<0.001$ & $<0.001$ & 0.021 & 0.044 \\
\hline $\begin{array}{l}\text { Baseline HBV pgRNA <4 } \\
\text { log copies/mL }\end{array}$ & $<0.001$ & $<0.001$ & $<0.001$ & 0.011 & & \\
\hline
\end{tabular}

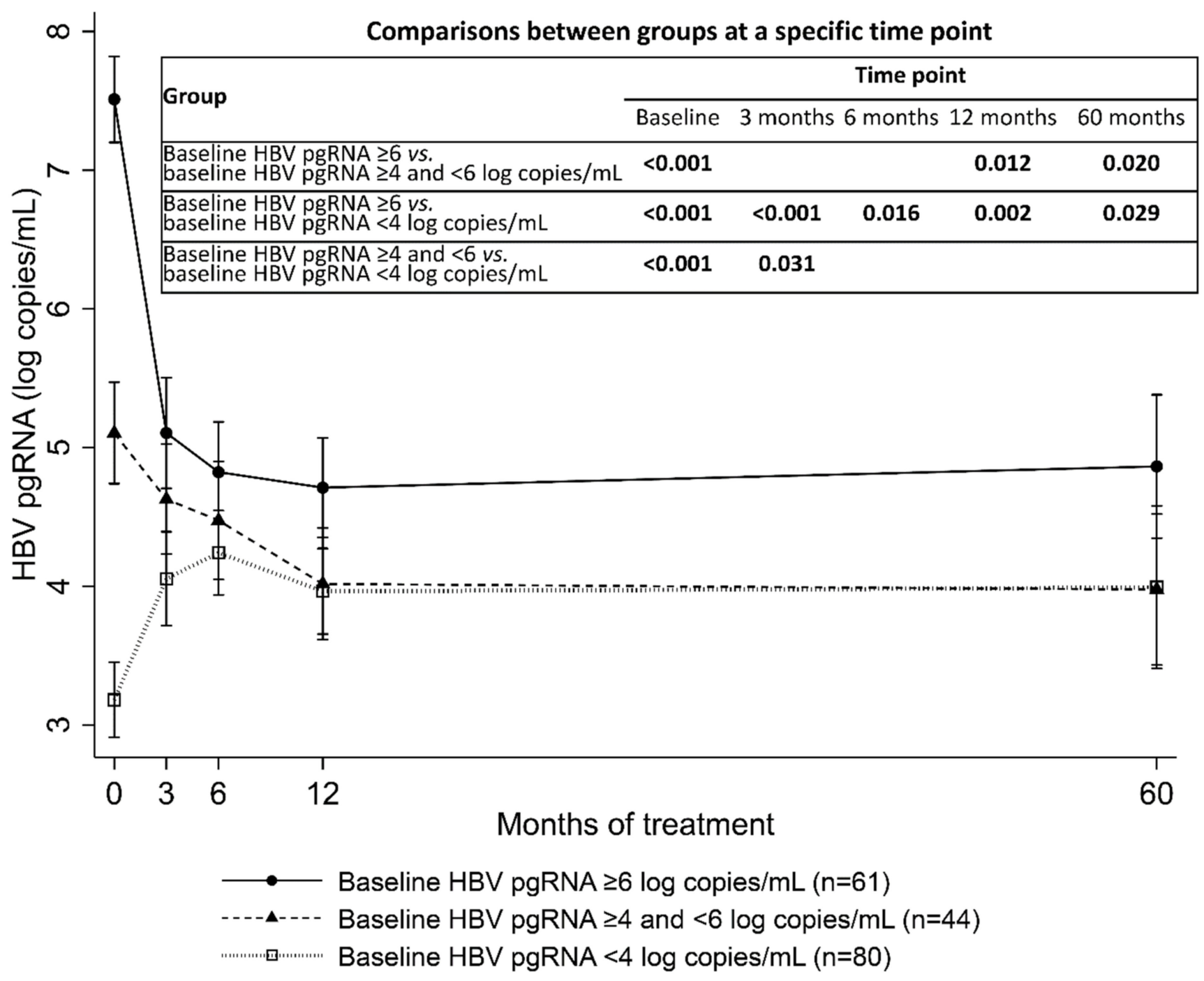

Figure 2. Serum HBV pgRNA kinetics during entecavir treatment, categorized by baseline serum HBV pgRNA levels. Error bars represent $95 \%$ confidence intervals. Significant $p$ values and one borderline $p$ value are presented.

\subsection{Baseline Serum HBV pgRNA and Virological Response}

The virological response to entecavir treatment was assessed in $171 \mathrm{CHB}$ patients, after excluding $8 \mathrm{HBeAg}$-positive and $6 \mathrm{HBeAg}$-negative patients with limited serum samples within the first year, as the limited serum samples prevented the virological response from being precisely determined. Kaplan-Meier analysis showed that baseline HBV pgRNA $<6.4 \log$ copies $/ \mathrm{mL}$ was associated with earlier virological responses compared with baseline HBV pgRNA $\geq 6.4 \log$ copies $/ \mathrm{mL}(p=0.0018$, Figure 5). Multivariate analysis showed that younger age, HBeAg negativity, and lower baseline HBV pgRNA were independently associated with earlier virological responses (age $<50$ years vs. $\geq 50$ years 
old: hazard ratio (HR): 1.54, 95\% confidence interval (CI): 1.03-2.30, $p=0.034 ; \mathrm{HBeAg}$ negativity vs. positivity: HR: 2.03, 95\% CI: $1.27-3.25, p=0.003$; HBV pgRNA $<6.4$ vs. $\geq 6.4 \log$ copies/mL: HR: 1.57, 95\% CI: 1.06-2.31, $p=0.023$, Table 2).

Comparisons between time points for a specific group

\begin{tabular}{|lccccc|}
\hline \multirow{2}{*}{ Group } & \multicolumn{5}{c|}{ Time point } \\
\cline { 2 - 6 } & $\begin{array}{c}\text { Baseline vS. } \\
\text { 3 months }\end{array}$ & $\begin{array}{c}\text { Baseline vs. } \\
6 \text { months }\end{array}$ & $\begin{array}{c}\text { Baseline vs. } \\
12 \text { months }\end{array}$ & $\begin{array}{c}\text { Baseline vs. } \\
60 \text { months }\end{array}$ & $\begin{array}{c}\text { months vs. } \\
6 \text { months }\end{array}$ \\
\hline $\begin{array}{l}\text { Baseline HBV pgRNA } \geq 6 \\
\text { log copies/mL }\end{array}$ & $<0.001$ & $<0.001$ & $<0.001$ & $<0.001$ & $\mathbf{0 . 0 0 2}$ \\
\hline $\begin{array}{l}\text { Baseline HBV HgRNA } \geq 4 \text { and }<6 \\
\text { log copies/mL }\end{array}$ & $<0.001$ & $<0.001$ & $<0.001$ & $<0.001$ & 0.001 \\
\hline $\begin{array}{l}\text { Baseline HBV pgRNA }<4 \\
\text { log copies/mL }\end{array}$ & $<0.001$ & $<0.001$ & $<0.001$ & $<0.001$ & 0.08 \\
\hline
\end{tabular}

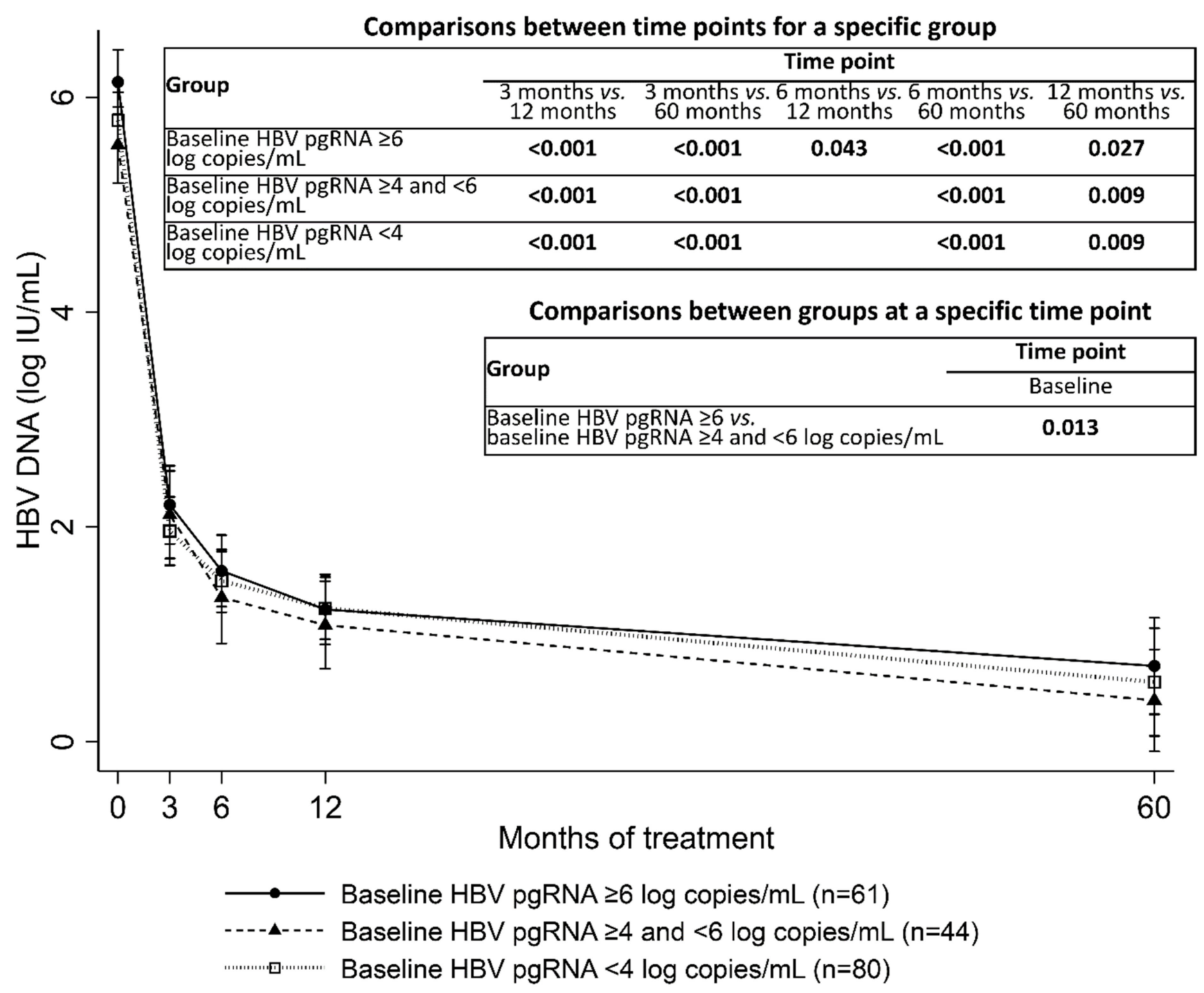

Figure 3. Serum HBV DNA kinetics during entecavir treatment, categorized by baseline serum HBV pgRNA levels. Error bars represent $95 \%$ confidence intervals. Significant $p$ values are presented. 
Comparisons between time points for a specific group

\begin{tabular}{|lccc|}
\hline \multirow{2}{*}{ Group } & \multicolumn{3}{c|}{ Time point } \\
\cline { 2 - 4 } & $\begin{array}{c}\text { Baseline vs. } \\
12 \text { months }\end{array}$ & $\begin{array}{c}\text { Baseline vs. } \\
60 \text { months }\end{array}$ & $\begin{array}{c}12 \text { months vs. } \\
60 \text { months }\end{array}$ \\
\hline Baseline HBV pgRNA $\geq 6$ log copies/mL & $<0.001$ & $<0.001$ \\
\hline Baseline HBV pgRNA $\geq 4$ and $<6$ log copies/mL & $\mathbf{0 . 0 2 0}$ & $<0.001$ & $\mathbf{0 . 0 1 7}$ \\
\hline Baseline HBV pgRNA $<4$ log copies $/ \mathrm{mL}$ & & $<0.001$ & $\mathbf{0 . 0 0 2}$ \\
\hline
\end{tabular}

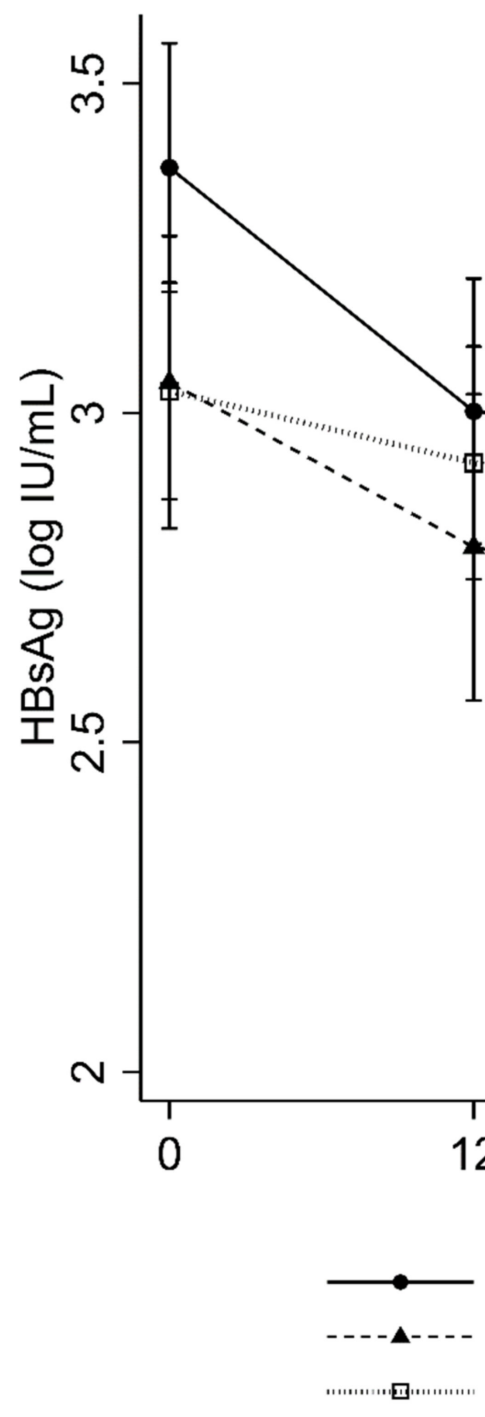

Comparisons between groups at a specific time point

\begin{tabular}{|lc|}
\hline Group & Time point \\
\cline { 2 - 3 } & Baseline \\
\hline $\begin{array}{l}\text { Baseline HBV pgRNA } \geq 6 \text { Vs. } \\
\text { baseline HBV pgRNA } \geq 4 \text { and }<6 \text { log copies } / \mathrm{mL}\end{array}$ & $\mathbf{0 . 0 2 8}$ \\
\hline $\begin{array}{l}\text { Baseline HBV pgRNA } \geq 6 \text { Vs. } \\
\text { baseline HBV pgRNA }<4 \text { log copies } / \mathrm{mL}\end{array}$ & $\mathbf{0 . 0 0 8}$ \\
\hline
\end{tabular}

Figure 4. Serum HBsAg kinetics during entecavir treatment, categorized by baseline serum HBV pgRNA levels. Error bars represent $95 \%$ confidence intervals. Significant $p$ values are presented.

\subsection{Correlation between Serum HBV pgRNA, HBV DNA, and HBsAg}

Before entecavir treatment, HBV pgRNA was positively correlated with HBV DNA and HBsAg in HBeAg-positive patients ( $r=0.28, p=0.04$ and $r=0.31, p=0.025$, respectively). By contrast, HBV pgRNA was not correlated with HBV DNA or HBsAg in HBeAg-negative patients. HBV DNA was positively correlated with HBsAg in both HBeAg-positive and HBeAg-negative patients $(r=0.58, p<0.00001$ and $r=0.47, p<0.00001$, respectively). After 1 year of entecavir treatment, HBV pgRNA was not correlated with HBsAg in either HBeAg-positive or HBeAg-negative patients (Supplementary Figure S1). 


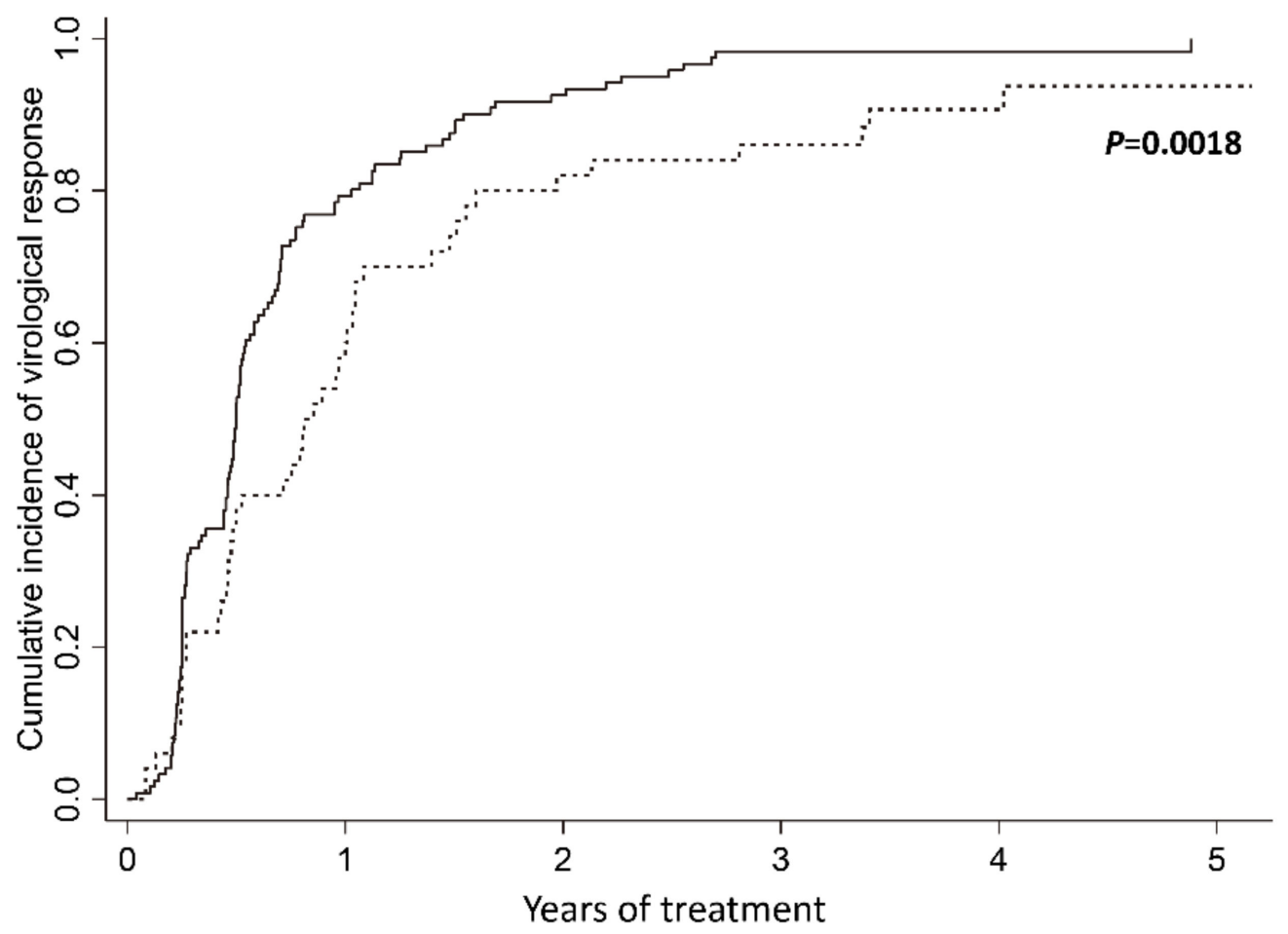

Number at risk

HBV pgRNA $<6.4 \quad 121$

25

9

HBV pgRNA $\geq 6.4 \quad 50$

21

9

1

1

0

1

\section{Baseline HBV pgRNA $<6.4 \log$ copies $/ \mathrm{mL}$ \\ Baseline HBV pgRNA $\geq 6.4 \log$ copies $/ \mathrm{mL}$}

Figure 5. Cumulative incidence of virological response during entecavir treatment.

Table 2. Univariate and multivariate analyses of factors associated with virological response during entecavir therapy.

\begin{tabular}{ccccccc}
\hline \multirow{2}{*}{ Factors } & \multicolumn{3}{c}{ Univariate Analysis } & \multicolumn{2}{c}{ Multivariate Analysis } \\
\cline { 2 - 7 } & HR & $\mathbf{9 5 \%}$ CI & $p$ Value & HR & $\mathbf{9 5 \%}$ CI & $p$ \\
\hline Age $(<50$ vs. $\geq 50$ years old) & 0.91 & $0.67-1.23$ & 0.54 & 1.54 & $1.03-2.30$ & $\mathbf{0 . 0 3 4}$ \\
\hline Sex (male vs. female) & 0.90 & $0.65-1.25$ & 0.53 & 0.73 & $0.50-1.07$ & 0.11 \\
\hline Baseline HBeAg (negative vs. positive) & 2.61 & $1.81-3.77$ & $<\mathbf{0 . 0 0 1}$ & 2.03 & $1.27-3.25$ & $\mathbf{0 . 0 0 3}$ \\
\hline HBV genotype (C vs. B) & 0.86 & $0.62-1.19$ & 0.36 & 0.96 & $0.64-1.42$ & 0.83 \\
\hline ALT $(\times$ ULN) & 0.99 & $0.96-1.02$ & 0.55 & 0.99 & $0.96-1.03$ & 0.64 \\
\hline Baseline HBsAg $(<4$ vs. $\geq 4 \log \mathrm{IU} / \mathrm{mL})$ & 2.56 & $1.57-4.17$ & $<\mathbf{0 . 0 0 1}$ & 1.74 & $0.93-3.25$ & 0.08 \\
\hline Baseline HBV DNA (<5 vs. $\geq 5 \log \mathrm{IU} / \mathrm{mL})$ & 1.98 & $1.44-2.74$ & $<\mathbf{0 . 0 0 1}$ & 1.28 & $0.86-1.92$ & 0.23 \\
\hline Baseline HBV pgRNA $(<6.4$ vs. $\geq 6.4 \log \mathrm{copies} / \mathrm{mL})$ & 1.73 & $1.22-2.45$ & $\mathbf{0 . 0 0 2}$ & 1.57 & $1.06-2.31$ & $\mathbf{0 . 0 2 3}$ \\
\hline Liver cirrhosis (yes vs. $\mathrm{no})$ & 1.33 & $0.96-1.84$ & 0.09 & 1.29 & $0.85-1.93$ & 0.23 \\
\hline
\end{tabular}

Significant $p$ values are presented in bold. Abbreviations: ALT, alanine aminotransferase; CI, confidence interval; HBeAg, hepatitis B e antigen; HBsAg, hepatitis B surface antigen; HBV, hepatitis B virus; HR, hazard ratio; pgRNA, pregenomic RNA; ULN, upper limit of normal.

\subsection{Factors Associated with Virological Relapse after Cessation of Entecavir Therapy}

In Part II, 47 patients with CHB were enrolled for analyzing the factors associated with virological relapse after cessation of entecavir therapy. Of these patients, $74.5 \%$ were men and 55.3\% were HBeAg-positive before receiving entecavir treatment. The median 
treatment duration was 4.32 (range, 2.00-8.22) years. At the end of treatment, the mean age, ALT, HBsAg, and HBV pgRNA levels were $46.8 \pm 11.9$ years, $0.74 \pm 0.85 \times \mathrm{ULN}$, $2.76 \pm 1.30 \log \mathrm{IU} / \mathrm{mL}$, and $3.90 \pm 0.97 \mathrm{log}$ copies $/ \mathrm{mL}$, respectively. The median HBV DNA level was 0.00 (range, 0.00-1.84) $\log \mathrm{IU} / \mathrm{mL}$ at the end of treatment. For the patients with available data on HBV genotypes, 20 had genotype B and 24 had genotype $C$. Compared with HBeAg-negative patients, HBeAg-positive patients were younger and had higher baseline HBsAg, baseline HBV DNA, and HBsAg levels at the end of treatment (Supplementary Table S4).

Kaplan-Meier analysis showed that "HBV pgRNA $\geq 1466$ copies $/ \mathrm{mL}$ " and "HBsAg $\geq 2 \log \mathrm{IU} / \mathrm{mL}$ or HBV pgRNA $\geq 1466$ copies $/ \mathrm{mL}^{\prime}$ at the end of treatment were associated with earlier virological relapse after cessation of entecavir therapy $(p=0.040$ and $p=0.038$, Supplementary Figure S2). Multivariate analysis showed that "HBsAg $\geq 2 \log \mathrm{IU} / \mathrm{mL}$ or HBV pgRNA $\geq 1466$ copies $/ \mathrm{mL}^{\prime}$ at the end of treatment was independently associated with earlier virological relapse after cessation of entecavir therapy (HR: 4.26, 95\% CI: $1.08-16.89, p=0.039$, Supplementary Table S5).

\subsection{Expression of Serum HBV pgRNA after HBsAg Loss}

In Part III, $34 \mathrm{CHB}$ patients who achieved HBsAg loss after nucleos(t)ide analogue treatment, $21 \mathrm{CHB}$ patients who achieved HBsAg loss spontaneously, 20 healthy subjects with negative $\mathrm{HBsAg}$ but positive anti-HBc, and 17 healthy controls with negative HBsAg and negative anti-HBc were enrolled for determining the expression of serum HBV pgRNA after HBsAg loss. Serum HBV pgRNA was not detected in CHB patients who achieved HBsAg loss spontaneously, healthy subjects with negative HBsAg but positive anti-HBc, or healthy controls with negative HBsAg and negative anti-HBc. Notably, $10 \mathrm{CHB}$ patients who received nucleos(t)ide analogue had serum HBV pgRNA higher than the LOD (1466 copies/mL) at or after HBsAg loss, with a median HBV pgRNA of 5.80 (range, 4.81-7.34) log copies/mL (Supplementary Table S6).

\subsection{Serum HBV pgRNA Kinetics in CHB Patients Who Achieved HBsAg Loss after Nucleos(t)ide Analogue Treatment}

In Part IV, $20 \mathrm{CHB}$ patients who achieved HBsAg loss after nucleos(t)ide analogue treatment with serial serum samples before and after HBsAg loss were enrolled. Five (25\%) and two (10\%) patients had HBV pgRNA going below the LOD (1466 copies/mL) before and at HBsAg loss, respectively. The other 13 (65\%) patients had serum HBV pgRNA higher than the LOD when they achieved HBsAg loss, with a median HBV pgRNA of 5.90 (range, 4.81-7.34) log copies/mL. Finally, all of these $20(100 \%)$ patients had HBV pgRNA going below the LOD within 3 years after achieving HBsAg loss (Figure 6 and Table 3). Anti-HBs became positive during HBsAg loss in one (5\%) patient and after HBsAg loss in 19 (95\%) patients (Figure 6). Longitudinal changes in HBsAg, HBV DNA, HBV pgRNA, and antibody to hepatitis B surface antigen (anti-HBs) are illustrated in Supplementary Figure S3.

\subsection{Factors Associated with HBsAg Loss after Nucleos(t)ide Analogue Treatment}

In Part $\mathrm{V}$, a total of $161 \mathrm{CHB}$ patients were enrolled for analyzing the factors associated with HBsAg loss after nucleos(t)ide analogue treatment (Table 3). Kaplan-Meier analysis revealed that a HBsAg decline of $\geq 1.5 \log \mathrm{IU} / \mathrm{mL}$ within the first year was associated with HBsAg loss $(p<0.0001$, Figure 7$)$. Multivariate analysis revealed that younger age and greater HBsAg decline within the first year were independently associated with HBsAg loss (age < 50 years vs. $\geq 50$ years old: HR: 9.81, 95\% CI: 1.23-77.94, $p=0.031$; HBAg decline $\geq 1.5 \log \mathrm{IU} / \mathrm{mL}$ vs. HBsAg decline <1.5 log IU/mL: HR: 53.59, 95\% CI: 3.83-749.5, $p=0.003$, Table 4). 


\section{(A) The timing when HBV pgRNA went below LOD (1466 copies/mL)}

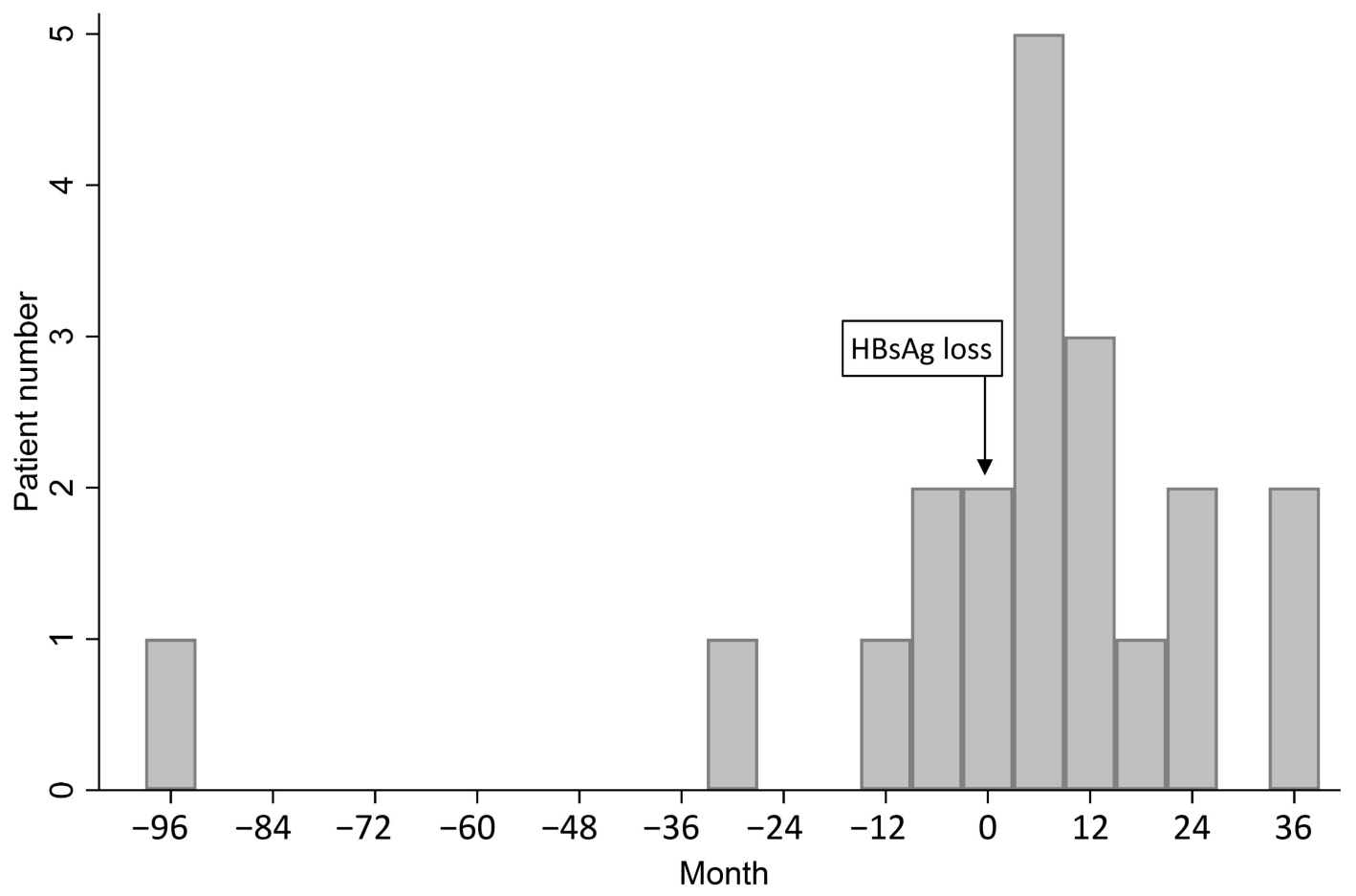

(B) The timing when anti-HBs became positive

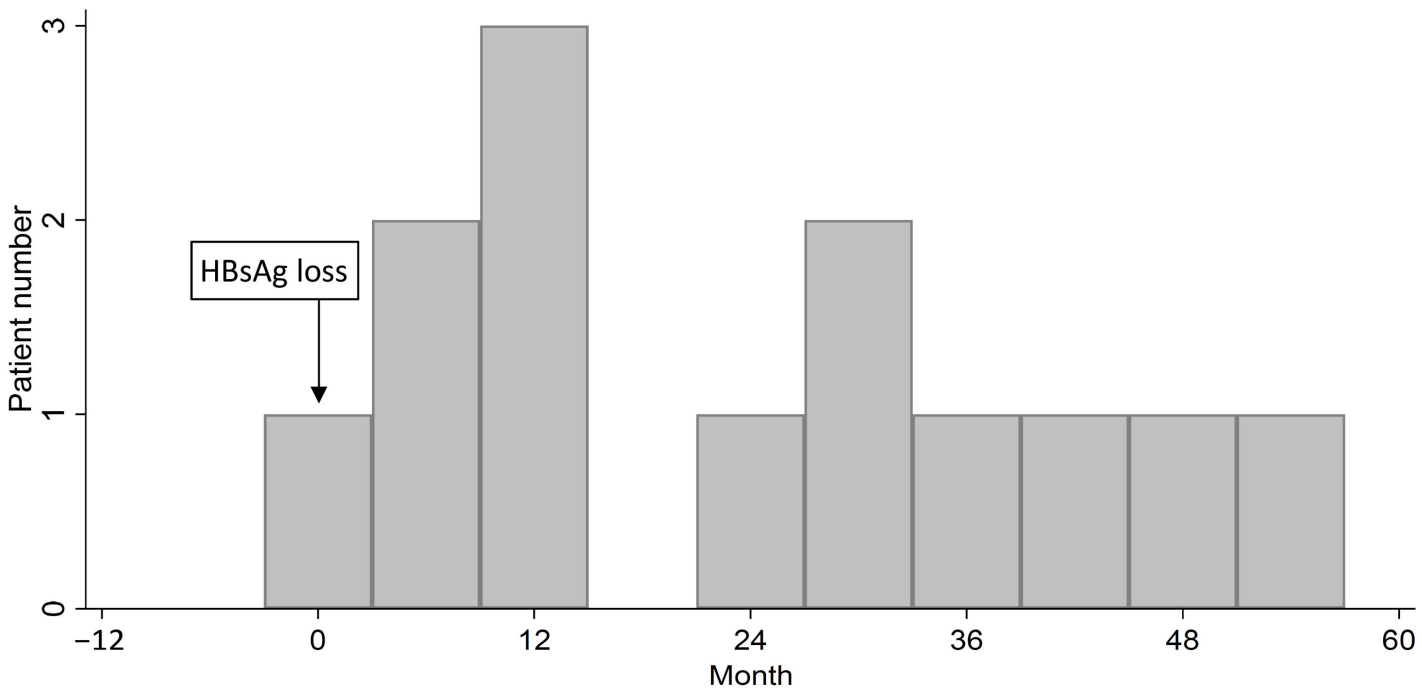

Figure 6. The timings when HBV pgRNA went below LOD (1466 copies/mL) (A) and anti-HBs became positive (B) in chronic hepatitis B patients who achieved HBsAg loss after nucleos(t)ide analogue treatment. 
Table 3. Clinical characteristics of 20 chronic hepatitis B patients who achieved HBsAg loss after nucleos(t)ide analogue treatment and 141 chronic hepatitis B patients who received nucleos(t)ide analogue treatment without HBsAg loss for analyzing the factors associated with HBsAg loss.

\begin{tabular}{|c|c|c|c|}
\hline Characteristics & $\begin{array}{l}\text { CHB Patients Achieved HBsAg Loss after } \\
\text { Nucleos(t)ide Analogue Treatment } \\
\qquad(n=20)\end{array}$ & $\begin{array}{l}\text { CHB Patients Received Nucleos(t)ide } \\
\text { Analogue Treatment without HBsAg Loss } \\
\qquad(n=141)\end{array}$ & $p^{a}$ \\
\hline Age at baseline (year) ${ }^{b}$ & $48.73 \pm 9.51$ & $51.41 \pm 11.97$ & 0.34 \\
\hline Male (\%) & $17 / 20(85 \%)$ & $94 / 141(66.7 \%)$ & 0.12 \\
\hline HBeAg-positive at baseline ${ }^{b}$ & $6 / 20(30 \%)$ & $45 / 141(31.9 \%)$ & 1.00 \\
\hline HBV genotype $(B: C)^{c}$ & $8: 2$ & $60: 63$ & 0.10 \\
\hline Baseline ALT $(\times \mathrm{ULN})^{b}$ & $6.75 \pm 11.03$ & $3.43 \pm 5.27$ & 0.35 \\
\hline Baseline HBsAg $(\log \mathrm{IU} / \mathrm{mL})^{\mathrm{b}}$ & $2.94 \pm 1.28$ & $3.17 \pm 0.73$ & 0.45 \\
\hline Baseline HBV DNA $(\log \mathrm{IU} / \mathrm{mL})^{\mathrm{b}}$ & $5.99 \pm 2.38$ & $5.87 \pm 1.68$ & 0.88 \\
\hline Baseline HBV pgRNA (log copies $/ \mathrm{mL})^{\mathrm{b}}$ & $5.14 \pm 2.05$ & $5.08 \pm 1.94$ & 0.92 \\
\hline Liver cirrhosis (\%) & $2 / 20(10 \%)$ & $51 / 141(36.2 \%)$ & 0.021 \\
\hline \multicolumn{4}{|l|}{ Nucleos(t)ide analogue } \\
\hline ETV $(\%)$ & $18 / 20(90 \%)$ & $141 / 141(100 \%)$ & \\
\hline $\operatorname{TDF}(\%)$ & $2 / 20(10 \%)$ & $0(0 \%)$ & \\
\hline Treatment time (year) & $5.12(2.39-14.10)$ & $4.91(1.84-11.29)$ & 0.24 \\
\hline Age at HBsAg loss (year) & $54.45 \pm 10.07$ & & \\
\hline \multicolumn{4}{|l|}{ HBV DNA at HBsAg loss (log IU /mL) } \\
\hline not detected $(\%)$ & $20 / 20(100 \%)$ & & \\
\hline \multicolumn{4}{|l|}{ HBV pgRNA at HBsAg loss } \\
\hline not detected (\%) & $0 / 20(0 \%)$ & & \\
\hline <LOD (1466 copies /mL) (\%) & $7 / 20(35 \%)$ & & \\
\hline$\geq$ LOD $(1466$ copies $/ \mathrm{mL})(\%)$ & $\begin{array}{c}13 / 20(65 \%) \\
5.90(4.81-7.34) \log \text { copies } / \mathrm{mL}\end{array}$ & & \\
\hline \multicolumn{4}{|l|}{ HBV pgRNA at the last follow-up (\%) } \\
\hline not detected $(\%)$ & $0 / 20(0 \%)$ & & \\
\hline <LOD (1466 copies /mL) (\%) & $20 / 20(100 \%)$ & & \\
\hline Anti-HBs-positive at the last follow-up (\%) & $13 / 20(65 \%)$ & & \\
\hline
\end{tabular}

Continuous variables are expressed as mean \pm standard deviation, except for treatment time and HBV pgRNA at HBsAg loss, which are expressed as median (range). Significant $p$ values are presented in bold. Abbreviations: ALT, alanine aminotransferase; Anti-HBc, antibody to hepatitis B core antigen; Anti-HBs, antibody to hepatitis B surface antigen; CHB, chronic hepatitis B; ETV, entecavir; $\mathrm{HBeAg}$, hepatitis B e antigen; HBsAg, hepatitis B surface antigen; HBV, hepatitis B virus; LOD, limit of detection; pgRNA, pregenomic RNA; TDF, tenofovir disoproxil fumarate; ULN, upper limit of normal. ${ }^{a} p$ value compared between patients with HBsAg loss and patients without HBsAg loss. ${ }^{b}$ Baseline means the time before receiving nucleos $(t)$ ide analogue treatment. ${ }^{c}$ HBV genotype was not determined in 10 patients with HBsAg loss and 18 patients without HBsAg loss because of low baseline HBV viral loads or limited baseline serum samples in these patients. 


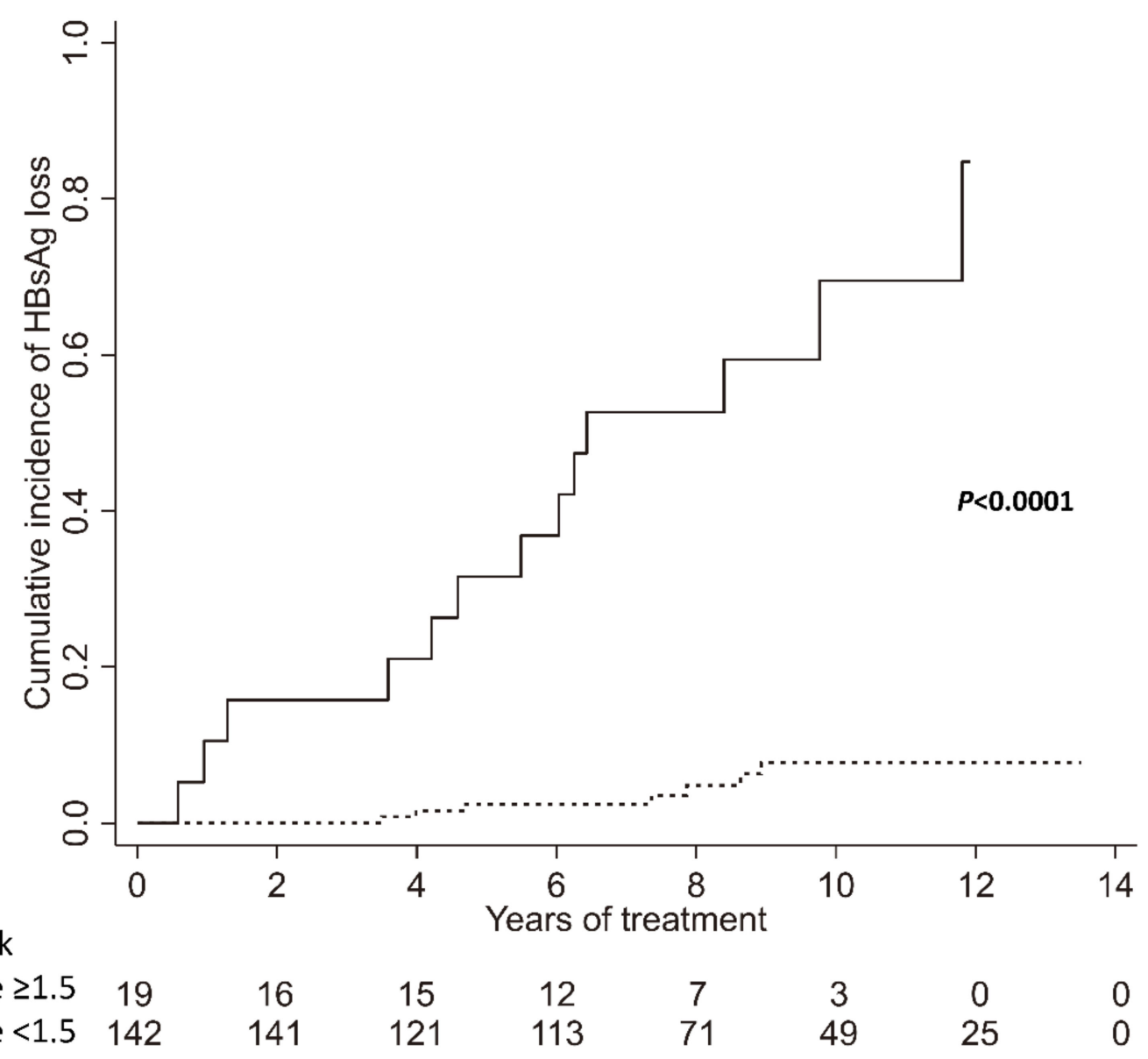

Number at risk

$\begin{array}{lcccccccc}\text { HBsAg decline } \geq 1.5 & 19 & 16 & 15 & 12 & 7 & 3 & 0 & 0 \\ \text { HBsAg decline }<1.5 & 142 & 141 & 121 & 113 & 71 & 49 & 25 & 0\end{array}$

\section{- HBsAg decline $\geq 1.5 \log \mathrm{IU} / \mathrm{mL}$ within the first one year HBsAg decline $<1.5 \log \mathrm{IU} / \mathrm{mL}$ within the first one year}

Figure 7. Cumulative incidence of HBsAg loss in chronic hepatitis B patients receiving nucleos(t)ide analogue treatment.

Table 4. Univariate and multivariate analysis of factors associated with HBsAg loss after nucleos(t)ide analogue treatment.

\begin{tabular}{|c|c|c|c|c|c|c|}
\hline \multirow{2}{*}{ Factors } & \multicolumn{3}{|c|}{ Univariate Analysis } & \multicolumn{3}{|c|}{ Multivariate Analysis } \\
\hline & HR & $95 \% \mathrm{CI}$ & $p$ Value & HR & $95 \% \mathrm{CI}$ & $p$ \\
\hline Age ( $<50$ vs. $\geq 50$ years old $)$ & 1.23 & $0.51-2.97$ & 0.64 & 9.81 & $1.23-77.94$ & 0.031 \\
\hline Sex (male vs. female) & 2.72 & $0.80-9.28$ & 0.11 & 2.10 & $0.34-13.10$ & 0.43 \\
\hline Baseline HBeAg (negative vs. positive) & 1.19 & $0.46-3.10$ & 0.72 & 1.53 & $0.11-20.81$ & 0.75 \\
\hline HBV genotype (C vs. B) & 0.25 & $0.05-1.17$ & 0.08 & 0.41 & $0.06-3.02$ & 0.38 \\
\hline Baseline ALT $(\times$ ULN $)$ & 1.04 & $0.99-1.10$ & 0.13 & 1.00 & $0.92-1.10$ & 0.97 \\
\hline Baseline HBsAg (<4 vs. $\geq 4 \log \mathrm{IU} / \mathrm{mL}$ ) & 0.60 & $0.19-1.86$ & 0.38 & 0.87 & $0.07-10.46$ & 0.91 \\
\hline Baseline HBV DNA (<5 vs. $\geq 5 \log \mathrm{IU} / \mathrm{mL}$ ) & 1.42 & $0.43-4.64$ & 0.57 & 6.84 & $0.78-60.40$ & 0.08 \\
\hline Baseline HBV pgRNA (<6.4 vs. $\geq 6.4 \log$ copies /mL) & 1.06 & $0.33-3.39$ & 0.92 & 3.35 & $0.43-26.42$ & 0.25 \\
\hline Liver cirrhosis (yes vs. no) & 0.21 & $0.05-0.89$ & 0.035 & 0.62 & $0.06-6.85$ & 0.70 \\
\hline HBsAg decline within the first one year ( $\geq 1.5$ vs. $<1.5 \log \mathrm{IU} / \mathrm{mL})$ & 17.57 & $6.99-44.17$ & $<0.001$ & 53.59 & $3.83-749.5$ & 0.003 \\
\hline
\end{tabular}

Significant $p$ values are presented in bold. Abbreviations: ALT, alanine aminotransferase; CI, confidence interval; $\mathrm{HBeAg}$, hepatitis B e antigen; HBsAg, hepatitis B surface antigen; HBV, hepatitis B virus; HR, hazard ratio; pgRNA, pregenomic RNA; ULN, upper limit of normal. 


\section{Discussion}

The study was the largest one to investigate long-term HBV pgRNA kinetics in CHB patients receiving nucleos(t)ide analogue treatment and the first one to study HBV pgRNA kinetics in those patients achieving HBsAg loss.

Serum HBV pgRNA levels decreased rapidly in the first 3 months in the high baseline HBV pgRNA group. The levels decreased gradually in the first 12 months in the medium baseline HBV pgRNA group. By contrast, the levels increased in the first 3 months in the low baseline HBV pgRNA group. The high baseline HBV pgRNA group had higher HBV pgRNA levels at baseline, 12 months, and 60 months than the medium and low HBV pgRNA groups. No significant differences were observed in HBV pgRNA levels at 6 months, 12 months, and 60 months between the medium and low HBV pgRNA groups. Our study demonstrated that baseline serum HBV pgRNA alone is insufficient for predicting the trajectory of HBV pgRNA. A more accurate description of HBV pgRNA trajectory would be provided by serial HBV pgRNA levels at baseline, 6 months, and 12 months after treatment.

HBV pgRNA is the template for reverse transcription and is normally degraded during the process of reverse transcription. Nucleos(t)ide analogues inhibit reverse transcription. While reverse transcription is inhibited, HBV pgRNA accumulates and is released in the circulation as HBV pgRNA-containing viral particles. Wang et al. showed the levels of HBV pgRNA virion increased after entecavir treatment in cell culture models and HBV transgenic mice [22]. Goncalves et al. developed a mathematical model that predicted a transient increase of HBV RNA levers during the first week of tenofovir treatment followed by a slower decline [32]. Our study illustrated that HBV pgRNA significantly increased within 3 months of entecavir treatment and remained higher than the baseline level in the low baseline HBV pgRNA group. We suppose longer antiviral treatment is needed to induce HBV pgRNA lower than the baseline in this group, especially since a significant proportion of them achieved HBsAg loss. Larger and more detailed kinetic studies are needed to characterize HBV pgRNA kinetics under nucleos $(\mathrm{t})$ ide analogue treatment, which would help us to understand HBV-host interactions and nucleos(t)ide analogues' mode of actions [33].

Even more remarkably, among the 20 patients achieving HBsAg loss, 13 (65\%) patients had serum HBV pgRNA higher than the LOD (1466 copies $/ \mathrm{mL}$ ) when they achieved HBsAg loss, with a median HBV pgRNA of 5.90 (range, 4.81-7.34) log copies/mL. Finally, all of these 20 patients had HBV pgRNA going below the LOD within 3 years after achieving HBsAg loss. Mak et al. showed that 3 of 19 (15.8\%) treatment-naive patients with HBsAg loss had detectable serum HBV RNA and HBcrAg [34]. These findings suggest that HBsAg loss does not necessarily equal complete cessation of viral transcription and translation. The sensitivity of quantitative assays, $\mathrm{HBsAg}$ escape mutants, and interference of $\mathrm{HBsAg}$ detection through immune complexes with anti-HBs in excess might be the reasons why cccDNA is still transcriptionally active in patients with undetectable HBsAg [35]. Further studies regarding serum HBV pgRNA kinetics in CHB patients achieving HBsAg loss and the time when HBV pgRNA becomes undetectable would improve the role of HBV pgRNA in clinical practice and its use as a surrogate marker of cccDNA.

Previous studies have shown that serum HBV pgRNA was positively correlated with HBV DNA before antiviral treatment in both HBeAg-positive and HBeAg-negative patients $[21,24,36]$. One study demonstrated that the correlation between HBV pgRNA and HBsAg before treatment was moderate in $\mathrm{HBeAg}$-positive patients but weak in $\mathrm{HBeAg}$ negative patients [36]. Another study showed that serum HBV pgRNA was positively correlated with HBsAg before treatment in HBeAg-positive patients, but not in HBeAgnegative patients [24]. Two studies have reported that serum HBV pgRNA was positively correlated with HBsAg after nucleoside analogue therapy [23,37]. Our study revealed that HBV pgRNA was positively correlated with HBV DNA and HBsAg before treatment in HBeAg-positive patients, but not in HBeAg-negative patients. The discrepancy may be explained by differences in patient characteristics, HBV genotypes, the presence of the $\mathrm{HBV}$ basal core promoter mutation, impaired virion productivity in HBeAg-negative 
patients, the proportion of HBsAg derived from the integrated HBV genome, and detection methods $[20,21,36,38,39]$.

Several studies have shown that serum HBV pgRNA was associated with treatment responses in patients with $\mathrm{CHB}$ receiving pegylated interferon or nucleos(t)ide analogue therapy [40-43]. Some studies have demonstrated that serum HBV pgRNA was associated with virological relapse after discontinuation of nucleos(t)ide analogue therapy [22,26-28]. Seto et al. showed that serum HBV pgRNA is useful for deciding on entecavir cessation in patients with $\mathrm{CHB}$, especially with low HBsAg levels [44]. Our study demonstrated that younger age, $\mathrm{HBeAg}$ negativity, and lower baseline HBV pgRNA were independently associated with earlier virological responses in patients receiving entecavir treatment, and

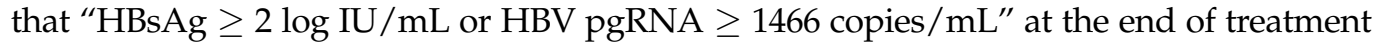
was independently associated with earlier virological relapse after cessation of entecavir therapy. All of these findings indicate that serum HBV pgRNA could serve as a biomarker for monitoring the efficacy of antiviral therapy.

Our study revealed that age below 50 years and HBsAg decline greater than $1.5 \log \mathrm{IU} / \mathrm{mL}$ within the first year were independently associated with HBsAg loss after nucleos(t)ide analogue therapy. These findings are compatible with previous studies. Lee et al. indicated that younger age, lower baseline HBsAg, rapid HBsAg decline at week 24, and achievement of sustained virological response were predictors of HBsAg loss after peginterferon therapy [45]. Jeng et al. demonstrated that shorter time to undetectable HBV DNA, greater HBsAg reduction during therapy, lower end-of-treatment HBsAg level, patients with sustained response, and untreated relapsers were predictors for HBsAg loss after cessation of nucleos(t)ide analogue therapy [46]. One recent study also demonstrated HBsAg to be superior to hepatitis B core-related antigen and HBV pgRNA in predicting HBsAg loss with peginterferon therapy [47].

Bai et al. showed that extracellular HBV RNAs comprised full-length pgRNA and $3^{\prime}$ RNA fragments degraded by the RNase $\mathrm{H}$ domain of polymerase from incomplete RT. These RNAs were localized in naked capsids and virions in cell culture supernatants, and they circulated as unenveloped capsids in the form of capsid-antibody complexes and virions in the blood of hepatitis B patients [48]. Another study showed that HBV RNA virion-like particles produced under nucleos $(\mathrm{t})$ ide analogue treatment also comprised full-length pgRNA and short RNA species. These short RNA species consisted of pgRNA splicing variants and 3 '-terminal truncations induced by nucleos $(\mathrm{t})$ ide analogue treatment; the truncations might be a major contributor to the replication deficiency and lack of infectivity of HBV RNA virion-like particles produced under nucleos(t)ide analogue treatment [49]. Anderson et al. showed that circulating HBV pgRNA is primarily full-length in patients receiving nucleos(t)ide analogue therapy [50]. Besides, Freitas et al. showed that serum HBV RNA derived not only from cccDNA but also from integrated HBV DNA sequences [51]. Further studies that clarify the production mechanisms of HBV pgRNA-containing viral particles and determine the expression of cccDNA-derived HBV RNA and integrant-derived HBV RNA in CHB patients are needed for further application of HBV RNA as a biomarker.

Our study has a few limitations. First, this was a retrospective study using stored serum samples. Second, only Asian patients infected with HBV genotype B or C were included. Third, serum HBV pgRNA levels were determined using an in-house method, which utilized DNase I for removal of viral DNA, with an LOD of 1466 copies/mL. Future prospective studies using commercial kits with a higher specificity and a lower LOD in large and diverse populations would provide more comprehensive descriptions of HBV pgRNA kinetics during antiviral treatment, especially for patients with low serum HBV pgRNA levels $[52,53]$. Fourth, HBsAg loss was determined by the Abbott Architect HBsAg assay (cut-off value: $0.05 \mathrm{IU} / \mathrm{mL}$ ) in this study. Future studies using a more sensitive qualitative assay or an ultrahigh sensitivity HBsAg assay (ICT-CLEIA, cutoff value: $0.0005 \mathrm{IU} / \mathrm{mL}$ ) would provide a more accurate assessment of functional cure [54,55].

In summary, our study demonstrated the kinetics and clinical utility of serum HBV pgRNA in CHB patients receiving long-term entecavir therapy and those achieving HBsAg 
loss. Baseline serum HBV pgRNA alone is insufficient for predicting the trajectory of HBV pgRNA. Serum HBV pgRNA was associated with virological responses during treatment and virological relapse after treatment withdrawal. Moreover, most patients had serum HBV pgRNA higher than the LOD (1466 copies/mL) when they achieved HBsAg loss. Further studies clarifying the production mechanisms of viral particles containing HBV pgRNA would provide an enhanced basis for further applying serum HBV pgRNA as a biomarker in antiviral treatment.

Supplementary Materials: The following are available online at https:/ /www.mdpi.com/article/10 $.3390 /$ microorganisms9061146/s1, Figure S1: title, Table S1: title. Figure S1: Correlation between serum HBV pgRNA, HBV DNA, and HBsAg. Figure S2: Cumulative incidence of virological relapse after cessation of entecavir therapy. Figure S3: HBV pgRNA kinetics in 20 chronic hepatitis B patients who achieved HBsAg loss after nucleos(t)ide analogue treatment. Table S1: Primers for HBV pgRNA amplification and detection. Table S2: The limit of detection for serum HBV pgRNA was 1466 copies/mL, as calculated by probit analysis. Table S3: Clinical characteristics of 185 chronic hepatitis B patients for studying the kinetics of serum HBV pgRNA during entecavir therapy, categorized by baseline HBV pgRNA levels. Table S4: Clinical characteristics of 47 patients with chronic hepatitis B for analysis of the factors associated with virological relapse after cessation of entecavir therapy, categorized by baseline HBeAg status. Table S5: Univariate and multivariate analyses of factors associated with virological relapse after cessation of entecavir therapy. Table S6: Clinical characteristics of 55 chronic hepatitis B patients who achieved HBsAg loss, 20 healthy subjects with negative $\mathrm{HBsAg}$ but positive anti-HBc, and 17 healthy controls with negative HBsAg and negative anti-HBc for assessing the expression of serum HBV pgRNA after HBsAg loss.

Author Contributions: I.-C.W. designed the study, analyzed data, and wrote the manuscript; W.-C.L. designed the experiments, performed the experiments, analyzed data, and wrote the manuscript; Y.-C.C., H.-C.C., and P.-N.C. provided clinical data and samples; T.-T.C. coordinated the study, gathered clinical data and samples, and composed the manuscript. All authors have read and agreed to the published version of the manuscript.

Funding: This work was supported by grants from the Ministry of Science and Technology (MOST 1082314-B-006-090) and National Cheng Kung University Hospital (NCKUH-10704038 and NCKUH-10802011).

Institutional Review Board Statement: The study was conducted according to the guidelines of the Declaration of Helsinki, and was approved by the Institutional Review Board of National Cheng Kung University Hospital (A-ER-106-065 approved on 23 February 2017, A-ER-106-443 approved on 17 January 2018, B-ER-107-366 approved on 16 January 2019).

Informed Consent Statement: Informed consent was obtained from all subjects involved in the study.

Data Availability Statement: The data that support the findings of this study are available from the corresponding author upon reasonable request.

Acknowledgments: We thank Tien-Ching Lin and Chien-Jui Huang for assistance with patient enrollment. We also thank Jia-Jhen Lin and Fang-Lin Chiu for sample preparation and clinical data collection.

Conflicts of Interest: The authors have no conflict of interest that pertain to this work.

\begin{abstract}
Abbreviations
ADV: adefovir; ALT, alanine aminotransferase; Anti-HBc, antibody to hepatitis B core antigen; Anti$\mathrm{HBs}$, antibody to hepatitis B surface antigen; cccDNA, covalently closed circular DNA; CHB, chronic hepatitis B; CI, confidence interval; CT, computed tomography; ETV, entecavir; HBcrAg, Hepatitis B core-related antigen; $\mathrm{HBeAg}$, hepatitis B e antigen; $\mathrm{HBsAg}$, hepatitis B surface antigen; HBV, hepatitis B virus; HCC, hepatocellular carcinoma; HCV, hepatitis $C$ virus; HIV, human immunodeficiency viruses; HR, hazard ratio; LAM, lamivudine; LOD, limit of detection; MRI, magnetic resonance imaging; pgRNA, pregenomic RNA; qPCR, quantitative real-time polymerase chain reaction; RT, reverse transcription; TDF, tenofovir disoproxil fumarate; ULN, upper limit of normal.
\end{abstract}




\section{References}

1. WHO. Global Hepatitis Report 2017; World Health Organization: Geneva, Switzerland, 2017.

2. European Association for the Study of the Liver. EASL 2017 clinical practice guidelines on the management of hepatitis B virus infection. J. Hepatol. 2017, 67, 370-398. [CrossRef]

3. Raffetti, E.; Fattovich, G.; Donato, F. Incidence of hepatocellular carcinoma in untreated subjects with chronic hepatitis B: A systematic review and meta-analysis. Liver Int. 2016, 36, 1239-1251. [CrossRef] [PubMed]

4. Terrault, N.A.; Lok, A.S.; McMahon, B.J.; Chang, K.-M.; Hwang, J.; Jonas, M.M.; Jr., R.S.B.; Bzowej, N.H.; Wong, J.B. Update on prevention, diagnosis, and treatment of chronic hepatitis B: AASLD 2018 hepatitis B guidance. Hepatology 2018, 67, 1560-1599. [CrossRef]

5. Sarin, S.K.; Kumar, M.P.; Lau, G.K.; Abbas, Z.; Chan, H.L.Y.; Chen, C.J.; Chen, D.-S.; Chen, H.L.; Chien, R.N.; Dokmeci, A.; et al. Asian-Pacific clinical practice guidelines on the management of hepatitis B: A 2015 update. Hepatol. Int. 2016, 10, 1-98. [CrossRef]

6. Lau, G.K.; Piratvisuth, T.; Luo, K.X.; Marcellin, P.; Thongsawat, S.; Cooksley, G.; Gane, E.; Fried, M.W.; Chow, W.C.; Paik, S.W.; et al. Peginterferon Alfa-2a, lamivudine, and the combination for HBeAg-positive chronic hepatitis B. N. Engl. J. Med. 2005, 352, 2682-2695. [CrossRef]

7. Tao, Y.; Wu, D.; Zhou, L.; Chen, E.; Liu, C.; Tang, X.; Jiang, W.; Han, N.; Li, H.; Tang, H. Present and Future Therapies for Chronic Hepatitis B. Adv. Exp. Med. Biol. 2019, 1179, 137-186. [CrossRef]

8. Buti, M.; Riveiro-Barciela, M.; Rodríguez-Frías, F.; Tabernero, D.; Esteban, R. Role of Biomarkers in Guiding Cure of Viral Hepatitis B. Semin. Liver Dis. 2019, 40, 49-60. [CrossRef]

9. Coffin, C.S.; Zhou, K.; Terrault, N.A. New and Old Biomarkers for Diagnosis and Management of Chronic Hepatitis B Virus Infection. Gastroenterology 2019, 156, 355-368.e3. [CrossRef]

10. Inoue, T.; Tanaka, Y. The Role of Hepatitis B Core-Related Antigen. Genes 2019, 10, 357. [CrossRef] [PubMed]

11. Testoni, B.; Lebossé, F.; Scholtes, C.; Berby, F.; Miaglia, C.; Subic, M.; Loglio, A.; Facchetti, F.; Lampertico, P.; Levrero, M.; et al. Serum hepatitis B core-related antigen ( $\mathrm{HBcrAg})$ correlates with covalently closed circular DNA transcriptional activity in chronic hepatitis B patients. J. Hepatol. 2019, 70, 615-625. [CrossRef] [PubMed]

12. Wang, L.; Cao, X.; Wang, Z.; Gao, Y.; Deng, J.; Liu, X.; Zhuang, H. Correlation of HBcrAg with intrahepatic hepatitis B virus total DNA and covalently closed circular DNA in HBeAg-positive chronic hepatitis B patients. J. Clin. Microbiol. 2019, 57, e01303-18. [CrossRef]

13. Tseng, T.-C.; Liu, C.-J.; Yang, W.-T.; Hsu, C.-Y.; Hong, C.-M.; Su, T.-H.; Tsai, C.-H.; Chen, C.-L.; Yang, H.-C.; Liu, C.-H.; et al. Serum hepatitis B core-related antigen level stratifies risk of disease progression in chronic hepatitis B patients with intermediate viral load. Aliment. Pharmacol. Ther. 2021, 53, 908-918.

14. Tseng, T.-C.; Liu, C.-J.; Hsu, C.-Y.; Hong, C.-M.; Su, T.-H.; Yang, W.-T.; Chen, C.-L.; Yang, H.-C.; Huang, Y.-T.; Kuo, S.F.-T.; et al. High Level of Hepatitis B Core-Related Antigen Associated with Increased Risk of Hepatocellular Carcinoma in Patients with Chronic HBV Infection of Intermediate Viral Load. Gastroenterology 2019, 157, 1518-1529.e3. [CrossRef]

15. Hosaka, T.; Suzuki, F.; Kobayashi, M.; Fujiyama, S.; Kawamura, Y.; Sezaki, H.; Akuta, N.; Suzuki, Y.; Saitoh, S.; Arase, Y.; et al. Impact of hepatitis B core-related antigen on the incidence of hepatocellular carcinoma in patients treated with nucleos(t)ide analogues. Aliment. Pharmacol. Ther. 2019, 49, 457-471. [CrossRef]

16. Chuaypen, N.; Posuwan, N.; Chittmittraprap, S.; Hirankarn, N.; Treeprasertsuk, S.; Tanaka, Y.; Shinkai, N.; Poovorawan, Y.; Tangkijvanich, P. Predictive role of serum HBsAg and HBcrAg kinetics in patients with HBeAg-negative chronic hepatitis B receiving pegylated interferon-based therapy. Clin. Microbiol. Infect. 2018, 24, 306.e7-306.e13. [CrossRef]

17. Wang, B.; Carey, I.; Bruce, M.; Montague, S.; Dusheiko, G.; Agarwal, K. HBsAg and HBcrAg as predictors of HBeAg seroconversion in HBeAg-positive patients treated with nucleos(t)ide analogues. J. Viral Hepat. 2018, 25, 886-893. [CrossRef] [PubMed]

18. Hsu, Y.-C.; Nguyen, M.H.; Mo, L.-R.; Wu, M.-S.; Yang, T.-H.; Chen, C.-C.; Tseng, C.-H.; Tai, C.-M.; Wu, C.-Y.; Lin, J.-T.; et al. Combining hepatitis B core-related and surface antigens at end of nucleos(t)ide analogue treatment to predict off-therapy relapse risk. Aliment. Pharmacol. Ther. 2018, 49, 107-115. [CrossRef] [PubMed]

19. Tseng, T.N.; Hu, T.H.; Wang, J.H.; Kuo, Y.H.; Hung, C.H.; Lu, S.N.; Jeng, W.-J.; Chen, C.-H. Incidence and factors associated with HBV relapse after cessation of entecavir or tenofovir in patients with HBsAg below $100 \mathrm{IU} / \mathrm{mL}$. Clin. Gastroenterol. Hepatol. 2020, 18, 2803-2812.e2. [CrossRef] [PubMed]

20. Liu, S.; Zhou, B.; Valdes, J.D.; Sun, J.; Guo, H. Serum Hepatitis B Virus RNA: A New Potential Biomarker for Chronic Hepatitis B Virus Infection. Hepatology 2019, 69, 1816-1827. [CrossRef]

21. Prakash, K.; Rydell, G.E.; Larsson, S.B.; Andersson, M.; Norkrans, G.; Norder, H.; Lindh, M. High serum levels of pregenomic RNA reflect frequently failing reverse transcription in hepatitis B virus particles. Virol. J. 2018, 15, 86. [CrossRef]

22. Wang, J.; Shen, T.; Huang, X.; Kumar, G.R.; Chen, X.; Zeng, Z.; Zhang, R.; Chen, R.; Li, T.; Zhang, T.; et al. Serum hepatitis B virus RNA is encapsidated pregenome RNA that may be associated with persistence of viral infection and rebound. J. Hepatol. 2016, 65, 700-710. [CrossRef]

23. Wang, J.; Peiyu, Q.; Li, G.; Shen, C.; Meng, Z.; Zheng, J.-M.; Jianming, Z.; Chen, S.; Zhang, X.; Zhu, M.; et al. Relationship between serum HBV-RNA levels and intrahepatic viral as well as histologic activity markers in entecavir-treated patients. J. Hepatol. 2018, $68,16-24$. [CrossRef] 
24. Huang, H.; Wang, J.; Li, W.; Chen, R.; Chen, X.; Zhang, F.; Xu, D.; Lu, F. Serum HBV DNA plus RNA shows superiority in reflecting the activity of intrahepatic cccDNA in treatment-naïve HBV-infected individuals. J. Clin. Virol. 2018, 99-100, 71-78. [CrossRef] [PubMed]

25. Gao, Y.; Li, Y.; Meng, Q.; Zhang, Z.; Zhao, P.; Shang, Q.; Li, Y.; Su, M.; Li, T.; Liu, X.; et al. Serum Hepatitis B Virus DNA, RNA, and HBsAg: Which Correlated Better with Intrahepatic Covalently Closed Circular DNA before and after Nucleos(t)ide Analogue Treatment? J. Clin. Microbiol. 2017, 55, 2972-2982. [CrossRef] [PubMed]

26. Fan, R.; Peng, J.; Xie, Q.; Tan, D.; Xu, M.; Niu, J.; Wang, H.; Ren, H.; Chen, X.; Wang, M.; et al. Combining Hepatitis B Virus RNA and Hepatitis B Core-Related Antigen: Guidance for Safely Stopping Nucleos(t)ide Analogues in Hepatitis B e Antigen-Positive Patients with Chronic Hepatitis B. J. Infect. Dis. 2020, 222, 611-618. [CrossRef]

27. Fan, R.; Zhou, B.; Xu, M.; Tan, D.; Niu, J.; Wang, H.; Ren, H.; Chen, X.; Wang, M.; Ning, Q.; et al. Association Between Negative Results from Tests for HBV DNA and RNA and Durability of Response After Discontinuation of Nucles(t)ide Analogue Therapy. Clin. Gastroenterol. Hepatol. 2020, 18, 719-727.e7. [CrossRef]

28. Carey, I.; Gersch, J.; Wang, B.; Moigboi, C.; Kuhns, M.; Cloherty, G.; Dusheiko, G.; Agarwal, K. Pregenomic HBV RNA and Hepatitis B Core-Related Antigen Predict Outcomes in Hepatitis B e Antigen-Negative Chronic Hepatitis B Patients Suppressed on Nucleos(T)ide Analogue Therapy. Hepatology 2020, 72, 42-57. [CrossRef] [PubMed]

29. Lin, T.-C.; Chiu, Y.-C.; Chiu, H.-C.; Liu, W.-C.; Cheng, P.-N.; Chen, C.-Y.; Chang, T.-T.; Wu, I.-C. Clinical utility of hepatitis B surface antigen kinetics in treatment-naïve chronic hepatitis B patients during long-term entecavir therapy. World J. Gastroenterol. 2018, 24, 725-736. [CrossRef] [PubMed]

30. Liu, W.-C.; Wu, I.-C.; Lee, Y.-C.; Lin, C.-P.; Cheng, J.-H.; Lin, Y.-J.; Yen, C.-J.; Cheng, P.-N.; Li, P.-F.; Cheng, Y.-T.; et al. Hepatocellular carcinoma-associated single-nucleotide variants and deletions identified by the use of genome-wide high-throughput analysis of hepatitis B virus. J. Pathol. 2017, 243, 176-192. [CrossRef]

31. Liu, W.-C.; Mizokami, M.; Buti, M.; Lindh, M.; Young, K.-C.; Sun, K.-T.; Chi, Y.-C.; Li, H.-H.; Chang, T.-T. Simultaneous Quantification and Genotyping of Hepatitis B Virus for Genotypes A to G by Real-Time PCR and Two-Step Melting Curve Analysis. J. Clin. Microbiol. 2006, 44, 4491-4497. [CrossRef]

32. Gonçalves, A.; Lemenuel-Diot, A.; Cosson, V.; Jin, Y.; Feng, S.; Bo, Q.; Guedj, J. What drives the dynamics of HBV RNA during treatment? J. Viral Hepat. 2021, 28, 383-392. [CrossRef] [PubMed]

33. Dahari, H.; Shlomai, A.; Cotler, S.J. Early HBV RNA kinetics under NA treatment may reveal new insights into HBV RNA dynamics and NA mode of action-more detailed kinetic studies are needed. J. Viral. Hepat. 2021, 28, 687-688. [CrossRef] [PubMed]

34. Mak, L.; Cloherty, G.; Wong, D.K.; Gersch, J.; Seto, W.; Fung, J.; Yuen, M. HBV RNA profiles in chronic hepatitis B patients under different disease phases and anti-viral therapy. Hepatology 2020. [CrossRef] [PubMed]

35. Raimondo, G.; Locarnini, S.; Pollicino, T.; Levrero, M.; Zoulim, F.; Lok, A.S.; Taormina Workshop on Occult HBV Infection Faculty Members. Update of the statements on biology and clinical impact of occult hepatitis B virus infection. J. Hepatol. 2019, 71, 397-408. [CrossRef]

36. Van Campenhout, M.J.H.; van Bommel, F.; Pfefferkorn, M.; Fischer, J.; Deichsel, D.; Boonstra, A.; van Vuuren, A.J.; Berg, T.; Hansen, B.E.; Janssen, H.L.A. Host and viral factors associated with serum hepatitis B virus RNA levels among patients in need for treatment. Hepatology 2018, 68, 839-847. [CrossRef]

37. Huang, Y.-W.; Takahashi, S.; Tsuge, M.; Chen, C.-L.; Wang, T.-C.; Abe, H.; Hu, J.-T.; Chen, D.-S.; Yang, S.-S.; Chayama, K.; et al. On-treatment low serum HBV RNA level predicts initial virological response in chronic hepatitis B patients receiving nucleoside analogue therapy. Antivir. Ther. 2014, 20,369-375. [CrossRef]

38. Volz, T.; Lutgehetmann, M.; Wachtler, P.; Jacob, A.; Quaas, A.; Murray, J.M.; Dandri, M.; Petersen, J. Impaired intrahepatic hepatitis B virus productivity contributes to low viremia in most HBeAg-negative patients. Gastroenterology 2007, 133, 843-852. [CrossRef]

39. Wu, Y.; Wen, J.; Xiao, W.; Zhang, B. Pregenomic RNA: How to assist the management of chronic hepatitis B? Rev. Med. Virol. 2019, 29, e2051. [CrossRef] [PubMed]

40. Zhang, M.; Li, G.; Shang, J.; Pan, C.; Zhang, M.; Yin, Z.; Xie, Q.; Peng, Y.; Mao, Q.; Xiao, X.; et al. Rapidly decreased HBV RNA predicts responses of pegylated interferons in HBeAg-positive patients: A longitudinal cohort study. Hepatol. Int. 2020, 14, 212-224. [CrossRef]

41. Farag, M.S.; van Campenhout, M.J.H.; Pfefferkorn, M.; Fischer, J.; Deichsel, D.; Boonstra, A.; van Vuuren, A.J.; Ferenci, P.; Feld, J.J.; Berg, T.; et al. Hepatitis B virus RNA as early predictor for response to pegylated interferon alfa in HBeAg-negative chronic hepatitis B. Clin. Infect. Dis. 2020, 72, 202-211. [CrossRef] [PubMed]

42. Luo, H.; Tan, N.; Kang, Q.; Pan, J.; Chen, H.; Xi, H.; Yu, M.; Xu, X. Hepatitis B virus pregenomic RNA status can reveal the long-term prognoses of chronic hepatitis B patients treated with nucleos(t)ide analogues. J. Viral Hepat. 2019, 27, 323-328. [CrossRef] [PubMed]

43. Van Bommel, F.; van Bommel, A.; Krauel, A.; Wat, C.; Pavlovic, V.; Yang, L.; Deichsel, D.; Berg, T.; Böhm, S. Serum HBV RNA as a predictor of peginterferon alfa-2a response in patients with HBeAg-positive chronic hepatitis B. J. Infect. Dis. 2018, 218, 1066-1074. [CrossRef]

44. Seto, W.-K.; Liu, K.S.; Mak, L.-Y.; Cloherty, G.; Wong, D.K.-H.; Gersch, J.; Lam, Y.-F.; Cheung, K.-S.; Chow, N.; Ko, K.-L.; et al. Role of serum HBV RNA and hepatitis B surface antigen levels in identifying Asian patients with chronic hepatitis B suitable for entecavir cessation. Gut 2021, 70, 775-783. [CrossRef] 
45. Lee, I.C.; Yang, S.S.; Lee, C.J.; Su, C.W.; Wang, Y.J.; Lan, K.H.; Lin, H.C.; Hou, M.-C.; Peng, C.-Y.; Huang, Y.H. Incidence and predictors of HBsAg loss after peginterferon therapy in HBeAg-negative chronic hepatitis B: A multicenter, long-term follow-up study. J. Infect. Dis. 2018, 218, 1075-1084. [CrossRef]

46. Jeng, W.-J.; Chen, Y.-C.; Chien, R.-N.; Sheen, I.-S.; Liaw, Y.-F. Incidence and predictors of hepatitis B surface antigen seroclearance after cessation of nucleos(t)ide analogue therapy in hepatitis B e antigen-negative chronic hepatitis B. Hepatology 2018, 68, 425-434. [CrossRef]

47. Lim, S.G.; Phyo, W.W.; Ling, J.Z.J.; Cloherty, G.; Butler, E.K.; Kuhns, M.C.; McNamara, A.L.; Holzmayer, V.; Gersch, J.; Yang, W.L.; et al. Comparative biomarkers for HBsAg loss with antiviral therapy shows dominant influence of quantitative HBsAg (qHBsAg). Aliment. Pharmacol. Ther. 2021, 53, 172-182. [CrossRef] [PubMed]

48. Bai, L.; Zhang, X.; Kozlowski, M.; Li, W.; Wu, M.; Liu, J.; Chen, L.; Zhang, J.; Huang, Y.; Yuan, Z. Extracellular Hepatitis B Virus RNAs Are Heterogeneous in Length and Circulate as Capsid-Antibody Complexes in Addition to Virions in Chronic Hepatitis B Patients. J. Virol. 2018, 92. [CrossRef]

49. Wang, J.; Sheng, Q.; Ding, Y.; Chen, R.; Sun, X.; Chen, X.; Dou, X.; Lu, F. HBV RNA virion-like particles produced under nucleos(t)ide analogues treatment are mainly replication-deficient. J. Hepatol. 2018, 68, 847-849. [CrossRef]

50. Anderson, M.; Gersch, J.; Luk, K.-C.; Dawson, G.; Carey, I.; Agarwal, K.; Shah, P.; Dusheiko, G.; Lau, D.; Cloherty, G. Circulating Pregenomic Hepatitis B Virus RNA Is Primarily Full-length in Chronic Hepatitis B Patients Undergoing Nucleos(t)ide Analogue Therapy. Clin. Infect. Dis. 2020. [CrossRef] [PubMed]

51. Freitas, N.; Lukash, T.; Gunewardena, S.; Chappell, B.; Slagle, B.L.; Gudima, S.O. Relative Abundance of Integrant-Derived Viral RNAs in Infected Tissues Harvested from Chronic Hepatitis B Virus Carriers. J. Virol. 2018, 92. [CrossRef]

52. Butler, E.K.; Gersch, J.; McNamara, A.; Luk, K.-C.; Holzmayer, V.; De Medina, M.; Schiff, E.; Kuhns, M.; Cloherty, G.A. Hepatitis B Virus Serum DNA andRNA Levels in Nucleos(t)ide Analog-Treated or Untreated Patients During Chronic and Acute Infection. Hepatology 2018, 68, 2106-2117. [CrossRef] [PubMed]

53. Kostyusheva, A.; Kostyushev, D.; Brezgin, S.; Volchkova, E.; Chulanov, V. Clinical Implications of Hepatitis B Virus RNA and Covalently Closed Circular DNA in Monitoring Patients with Chronic Hepatitis B Today with a Gaze into the Future: The Field Is Unprepared for a Sterilizing Cure. Genes 2018, 9, 483. [CrossRef] [PubMed]

54. Kusumoto, S.; Tanaka, Y.; Suzuki, R.; Watanabe, T.; Nakata, M.; Sakai, R.; Fukushima, N.; Fukushima, T.; Moriuchi, Y.; Itoh, K.; et al. Ultra-high sensitivity HBsAg assay can diagnose HBV reactivation following rituximab-based therapy in patients with lymphoma. J. Hepatol. 2020, 73, 285-293. [CrossRef]

55. Shinkai, N.; Kusumoto, S.; Murakami, S.; Ogawa, S.; Ri, M.; Matsui, T.; Tamori, A.; Toyoda, H.; Ishida, T.; Iida, S.; et al. Novel monitoring of hepatitis B reactivation based on ultra-high sensitive hepatitis B surface antigen assay. Liver Int. 2016, 37, 1138-1147. [CrossRef] [PubMed] 